معلومات الانشطة الإبداعية وتقدير ..

معلومات الاتشطه الإبداعيه وتقدير مصادر التطور التكنولوجي*

\author{
د. نو نول هاسم علي الشهوان

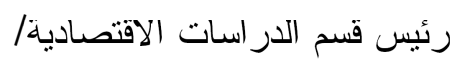 \\ مركز الدراسات الإقليمية-جامعة الموصل فلئل
}

تهدف هذه الدراسة إلى تحليل واقع معلومات الأشثطة الإبداعية الــصناعية و اختبـار

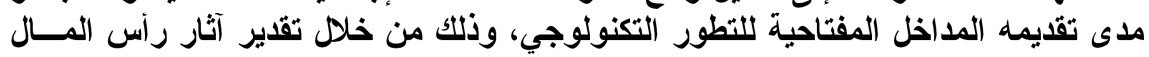

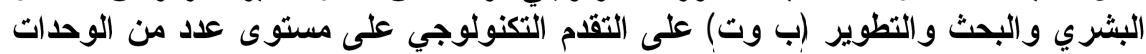

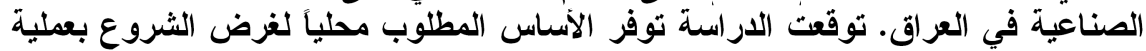

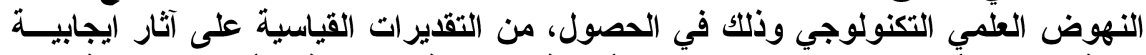

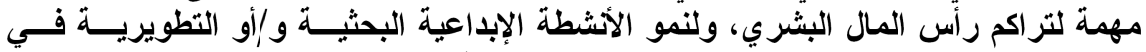

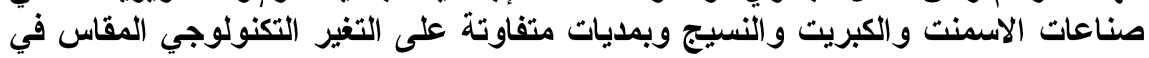

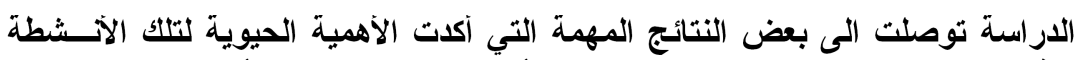

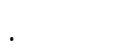

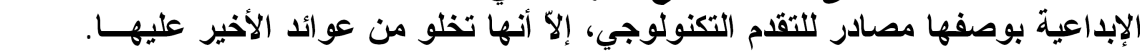

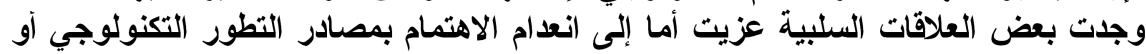

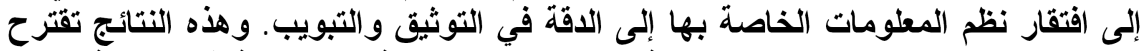

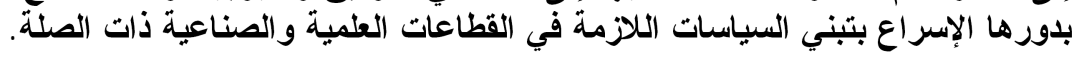

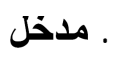

"إن تتمبة المو اهب البشرية طبلة مدة التعلم او الدراسة او العمل غالبا ما

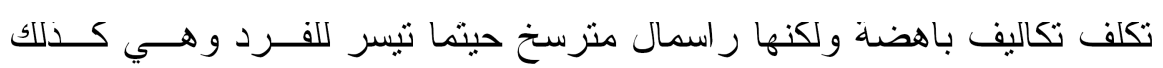

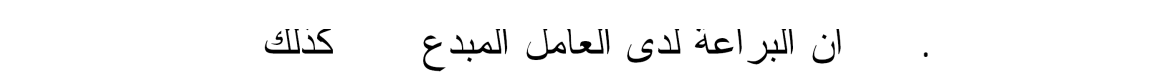

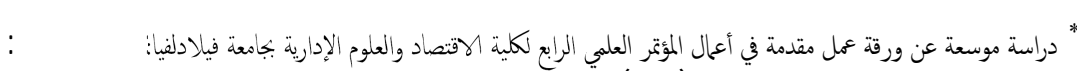

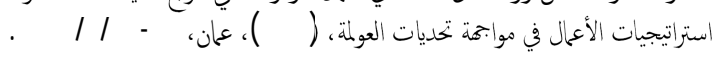


وجسر التسهيل إيصال المواهب، وفي كل الاحو ال تكون مكلفة إيـضا، ولكنهـ

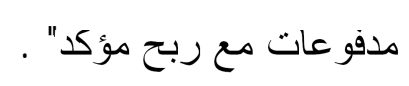

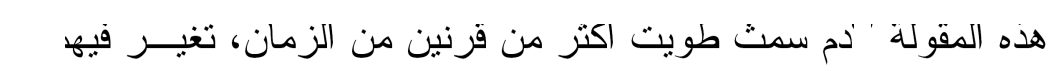

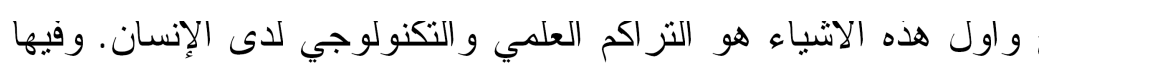

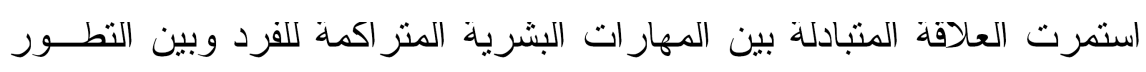
العلمي و التكنولوجي للمجتمع بالتقاعل في كلا الاتجاهين. فضدا عن ان العلاقة

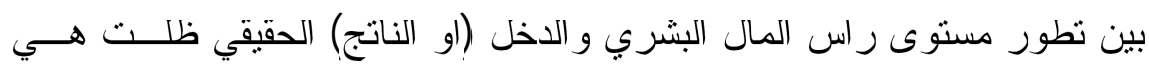

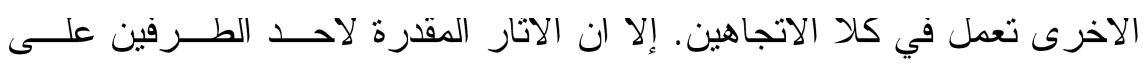

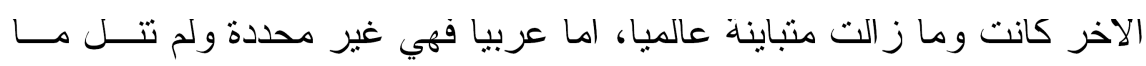

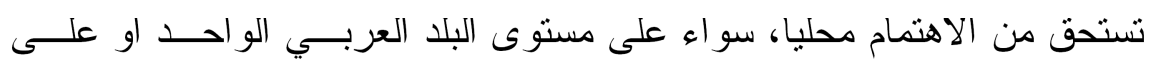
مستوى منظمة الاعمال الصناعية فيه. و الإتباتات الرقمية المتاحة عربيا عن الانشطة الإبداعية لم تــنمكن مـن تقديم ما بدعم تلك العلاقات او دحضها محليا، لا لشئ سوى ان معظم الجهــود المنشورة تعنمد في الاساس على قاعدة البيانات المنيسرة وعلى نظم المعلومات المتاحة وما هو موجود من تلك الانشطة، فضلا عن المتغيـر ات ذات الــصلة ودقة الارقام الني توتقها. هذا يعني ان النمادج النظرية المطروحة للنمو الافتصادي نشير إلـى ان تز اكم راس المال البشري هو محدد مهم في النمو، وان الاجور الاعلى مرتبطـــة

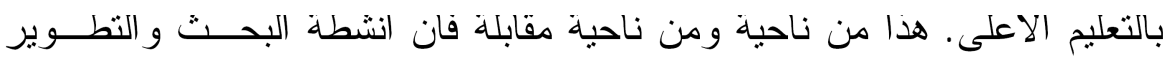

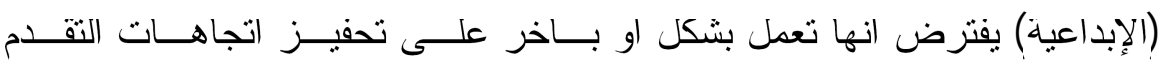

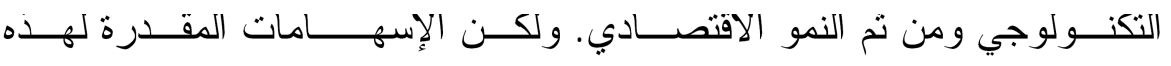

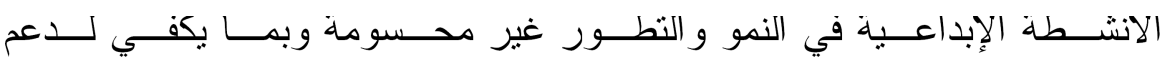


$[\mathbf{9 0}]$

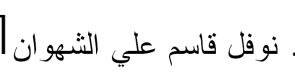

السياسات الكلية للاستتمار الافضل. فما هي اهمية الاسس التي تدعم تحققهـــا إن تحققت الا وهي نظم المعلومات في هذا الصدد؟

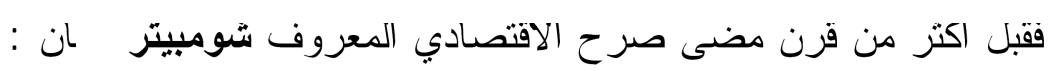
"في ارباح المنظمين للعمليات الإنتاجية تكمن البذور الاولى للتروة وفي تــاريخ

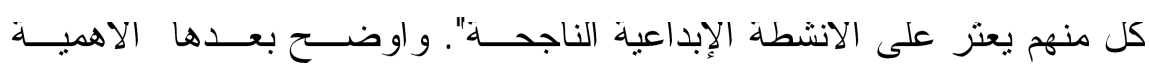

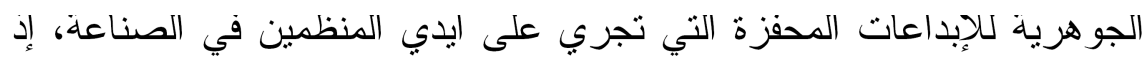
تكمن في تقديمها المفتاح الرئيس لكل العالم الر اسمالي و الأئنماني، وانت النتمي ـة بوصفها عملية إدارية و اقتصادية هي عبارة عن إعادة بناء خلاق وهي المسئولة

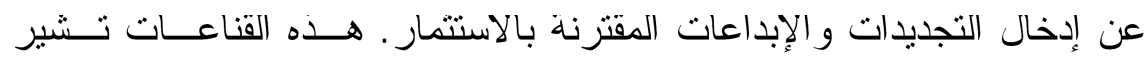
بوضوح إلى ان الإبداعات دالة في التقام التكنولوجي قبل ان تكون كــلك ف في النمو الاقتصادي. فهل تحققت هذه القناعات؟ بو بإِ تهذف هذه الدر اسة إلى التعرف على اهمية نظم المعلومــات الخاصـــة بالانشطة الإبداعية ودورها في تقدير مصادر النطور التكنولوجي، وذلك مسن خلال در اسة إسهامات كل من المتغير ات الإبداعية المقاســة فــي عــدد مــن المنظمات الصناعية المحلية وتقدير ادائها في الإسهام في بناء معدلات النقــدم النكنولوجي المحتسبة فيها. يشير مصطلح الانشطة الإبداعية إلى جهود التتمية البـشرية تـــ إلـى لـى الابحاث الاساسية و النطبيقية و ابحاث تكييف النكنولوجيات المستوردة و النطوير كما سيتم تقصيلها بعد قليل. اما معدلات التقدم التكنولوجي فيتم احتسابها علــى طريقة سولوع من معادلة النمو الاقتصادي بعد طرح إسهامات عناصر الإنتاج التقليدية، كما سيلاحظ لاحقا. ويقصد بمصطلح الثقلم التكنولوجي مقياس التغير النكنولوجي عندما تكون معدلاته موجبة. 
وقد وقع الاختيار على تلاتة من بين عدد مــن المنظمــات الــصناعية

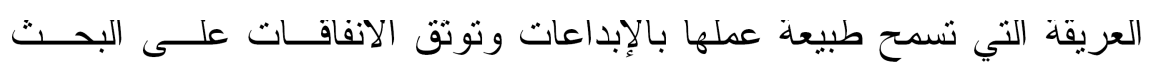

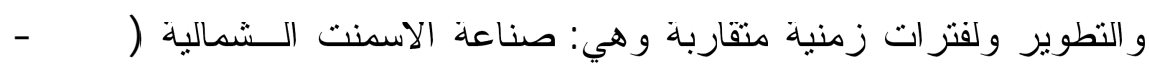

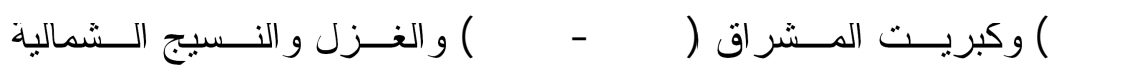
.(199V-197V)

وهنا يفترض ان بناء نظام معلومات مفصل ودقيق بما بعبر عن و اقــع

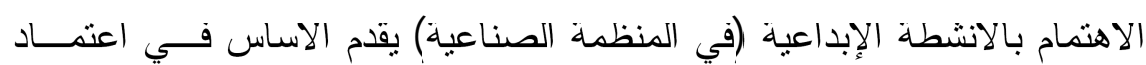
الادو ات الجوهرية اللازمة لسياسات النطوير التكنولوجي المطلوب (سواء على الإبه مستوى المنظمة الواحدة او على مستوى المجتمع) في البيئات النامية و المنقدمة بسو اء. وللتحقق من هذه الفرضبة فان المنهجية المعتمدة في هذا الصدد تتبنـى

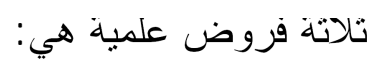

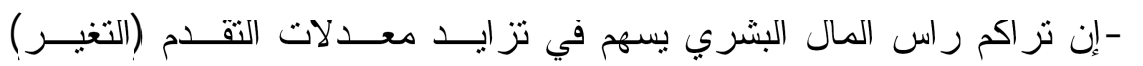
النكنولوجي المقاس. r - إن الجهود الإبداعية المحلية المتر اكمة منل راس مال الابحاث و /او راس مال التطوير نرنبط بعلاقة ايجابية مع (النقدم) النكنولوجي.

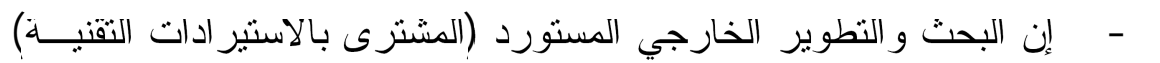
له اتار ايجابية على النقام التكنولوجي المقاس. إن الاتجاه التحليلي للار اسة حقيقة يقوم على افتر اض ضمني مفــاده انت كل ما يؤثز معنويا في زيادة الإنتاج (من منغير ات الانشطة الإبداعبـة) يــؤئر كذلك في تز ايد معدلات النقدم النكنولوجي ومن نم معدلات النمو الاقتصادي في

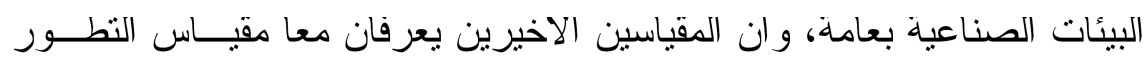
التكنولوجي لهذه البيئات. 
[qV] نوفل قاسم علي الثنهو ان. معلومات الانشطة الإبداعية وتقدير .ج

هذا ما تحاول هذه الدر اسة التحقق منه محليا، إذ ان: تطــــور المنظمـــة

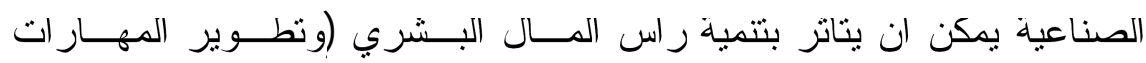
البشرية) وبالانشطة الإبداعبة الاخرى متل انشطة البحث او انشطة النطوير او اونية

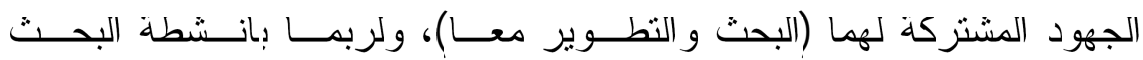
و النطوير (ب وت) المستورد (المجسد بمستوردات تكنولوجية بانو اعهـا) . فــإدا كان 0

النمو الاقتصادي = دالة في (النقام النكنولوجي، ونمو عناصر الإنتاج)

النطور ( الاقتصادي)= دالة في (النقدم التكنولوجي، النمو الاقتصادي)

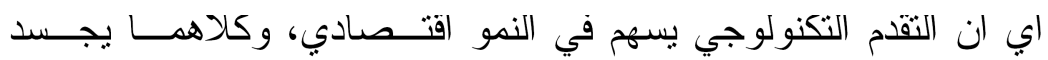
النطور ، ومن وجهة نظر هذه الدر اسة يكون:

التقدم النكنولوجي= دالة في (نمو راس المال البشري ونمو انشطة البحث و إو النطوير و البحث و النطوير المستورد ).

هذه المفاهيم بحاجة إلى قباس علمي دقيق لغرض التعامل معها بوصفها

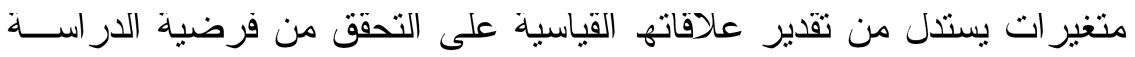
في اعلاه. وقبل ذلك لابد من تحديد ما ير اد بالانشطة الإبداعية بهذا الــصدد.

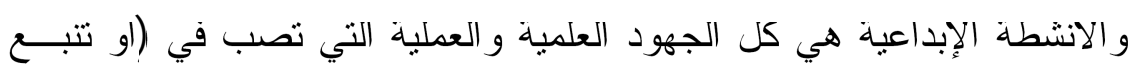

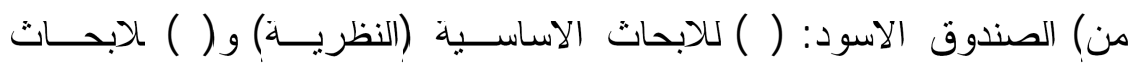

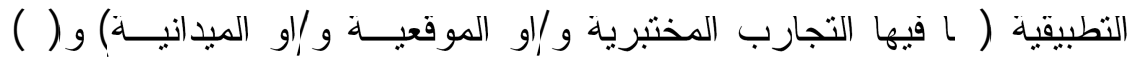

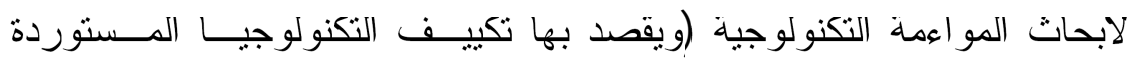

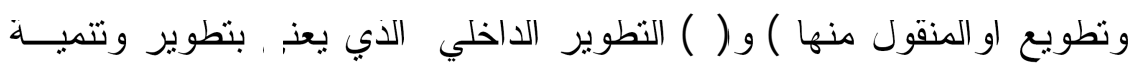

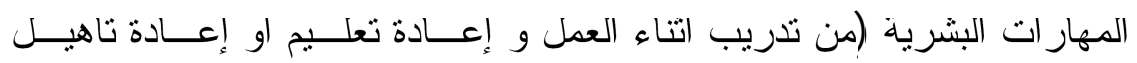
ومو اكبة الاجور و الحوافز للإنتاجية بشقيها الإنتاجية الفردية و الإنتاجية البحتية 


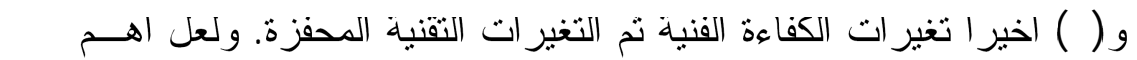
يساهم في تدعيم التغير ات الاخيرة المبتكر ات و المكتشفات العلمية و التجديــــات

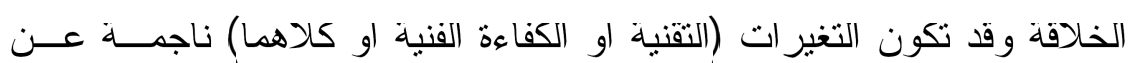
و احدة او اكتر من انشطة البحث و /او النطوير، فضلا عن كل ما يصب فـي زيادة الإنتاج وتحسين الإنتاجية التقليدية.

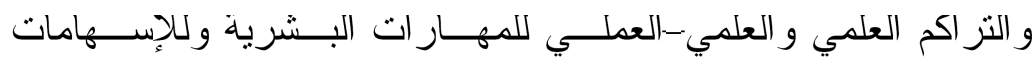
المعرفية في الإنتاجية بمكن ان يقدم افضل تقريب لمفهوم راس المال البشري.

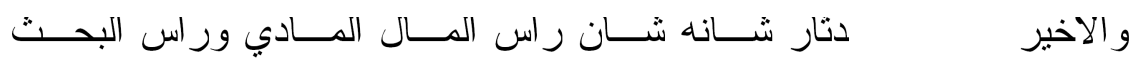
و التطوير ـ وتكمن مشكلة البحث التجريبية في هذا السياق بالمفـــاهيم المتعـددة لتعريف راس المال البشري وندرة المقاييس التي يمكن اعتمادها فــي التقــدير فضلا عن ندرة معايير الحكم على دقة المعتمد منها. وبعبــارة اخــرى نـــدرة المعلومات المبوبة و التقصيلية بشكل علمي سليم و افتقــــار الــنظم المعلوماتيـــة لمقومات المعولية التي يمكن اعتمادها في قياس راس المال البشري وفي نقدير دوره في نطور المنظمة الصناعبة بالتالي. المبحث التاني القادم يُسلط الضوء بشكل مركز على اهم الادبيــات ذات الصلة بتطور البة التعامل مع مفاهيم الانشطة الإبداعية و التقدم التكنولــوجي.

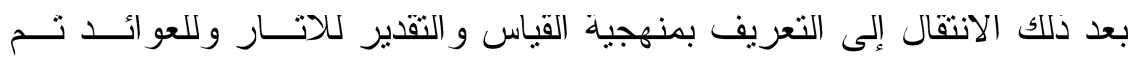
مر احل التحليل القياسي التي يعالجها المبحث التالي؛ الر ابع، للحــصول علـى الملامح الرئيسة لابعاد صورة الو اقع المحلي عن معلومات الانشطة الإبداعيـة فئة في تقدير مصادر النطور النكنولوجي من خلال تقدير وتحليل دور الإبداعات في التقدم التكنولوجي في عدد من الصناعات التحويلية فـي العـر اق. وفـي لـي الخاتمة استتاجات تثقرد هذه الدر اسة برسمها عربيا. 
r - راس المال البشري والتقدم التكنولوجي

مع مستهل القرن الحادي و العشرين افصح الاتجاه العــالمي العــام فـي

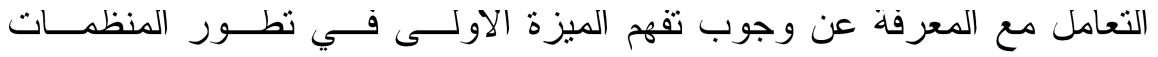

و المجتمع بسو اءو الكامنة في الإمكانيات البشرية، وفي التعود على التعلم بـدون

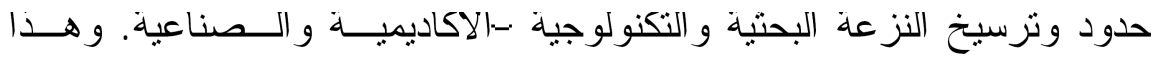

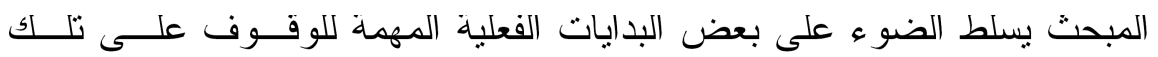

فيسبعينيات القرن الماضي اكد الباحثون المختصون في التتمية امنــال

كارنوي " ومن خلال تحليل النمو الاقتصادي طويل-الامد للو لايات المتحدة إلى في

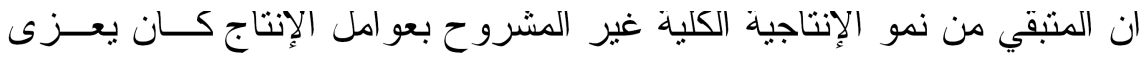

إلى التقدم التكنولوجي. و إن اهم مكونات هذا المنبقي هو الاستتمار في العنصر

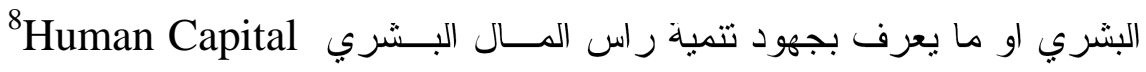

فضلا عن التحسن النوعي في راس المــال المــادي

و الطبيعي.

ور اس المال البشري تم قياسه من قبــل العديــــــــن البــاحتين مـ ـنهم

الاقتصادي ترلكو وذلك بمفردات التحصيل العلمـي او بـسنو ات الدراســة او

بمستويات الدرجات الاكاديمية المتحصلة بحسب مجال وتصنيف الدر اســة، او

بسنوات الخبرة (الوظيفية) او بتز ايد الاجور الحقبقيــة.مثة لـل هــــهـ المقـــييس استخدمتها إلى جانب متغبرات اخرى منل معدلات الانخر اط في نقابات العمال

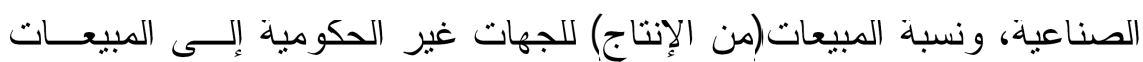
الكلبة و اللاستقر ارية الدورية لناتج الصناعة.. في قياس تلك العلاقـات لــشرح 
معدلات نمو إنتاجية العنصر الكلي مقياس التقدم التكنولوجي غير المجسد فـي دالة الإنتاج.

وقد عتر ترلك على إسهامات كبيرة لر اس المال البـشُري فــي التقــدم

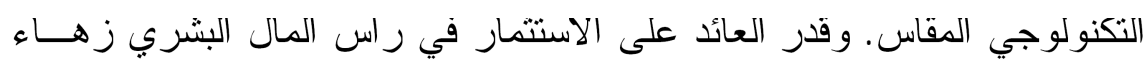

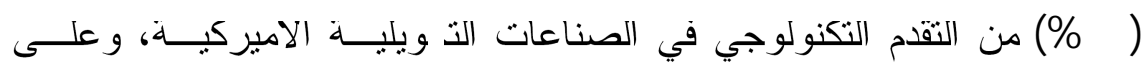

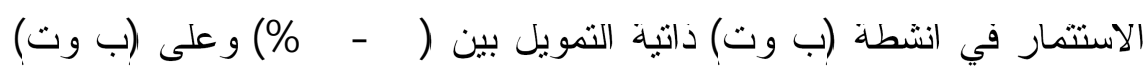

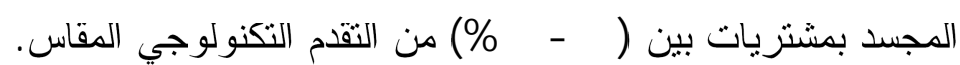

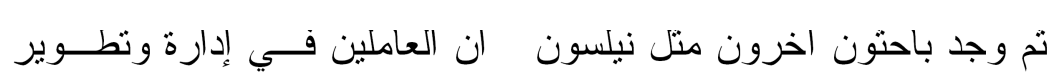

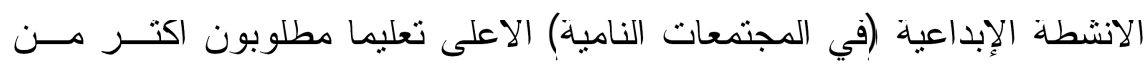

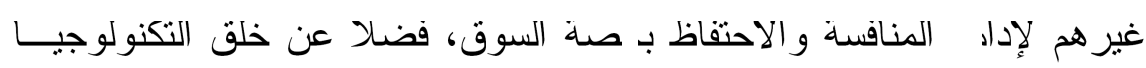

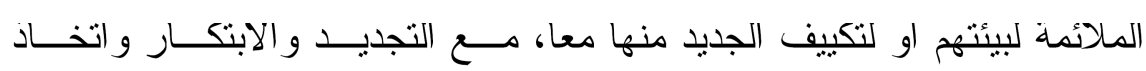

$$
\text { القز ار ات المتعلقة بجدارتها و اهليتها. }
$$

وفي البلدان النامية فان المفتاح إلى جهود التتمية و التطور فيها كما انشار

كندلبركر مع هيرك" هو تكوين راس المال البشري. إذ نستمر الاســتشمار ات

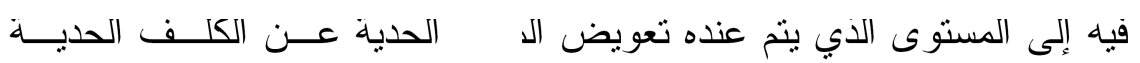

للانفاقات الإضافية وهذه طبعا وجهة نظر كلاسبكية - جديدة ذات ابعاد متعددة

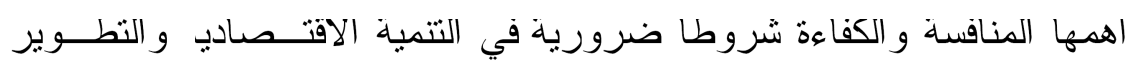

$$
\text { الإداري. }
$$

وفي كوريا الجنوبية وجد ان دور نز اكم راس المال الطبيعي في النمــــ

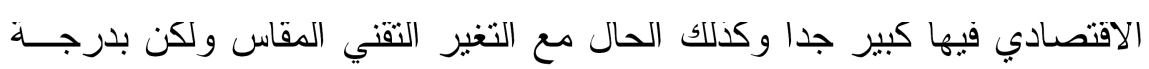

اقل. اما دور راس المال البشري فكان معتدلا على امتداد العقود النتاتة الاخبرة

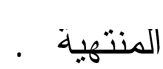




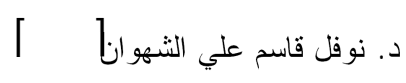

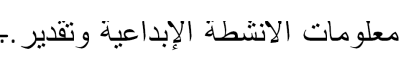

ووجد في المكسيك ان عو ائد راس المال البشري ترتفـع مــع التغيـر

التكنولوجي، وان هذا الارتفاع مرتبط ايجابيا بالزيادات في حجم الإنتاج. وبهذا

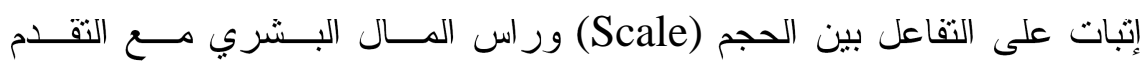
التكنولوجي" إن.

كما اكد عمل اخر على ان المحرك غير المحـــود للنمــو فــي الــدول

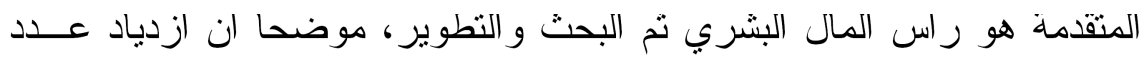

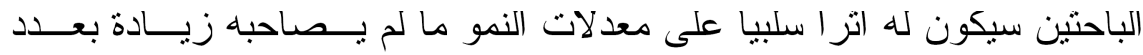

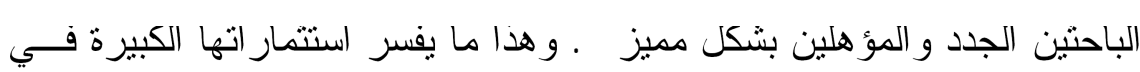
هذين العنصرين في القرن الماضي وفنشها بتحقيق معدلات نمو مرتفعة.

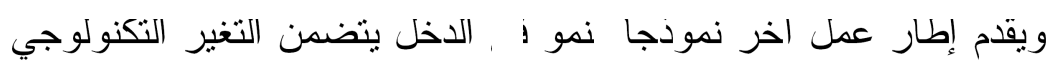

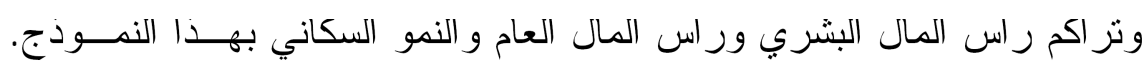

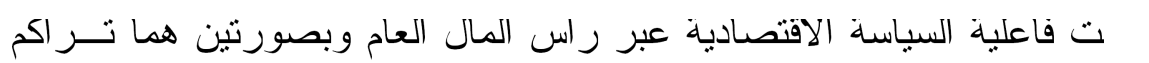

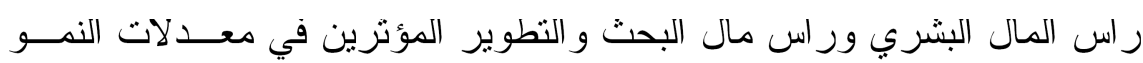
الاقتصادي اللأبل الطويل 10.

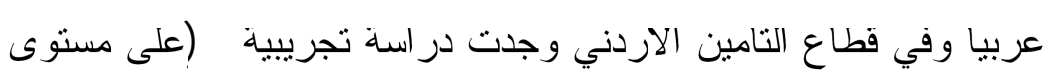

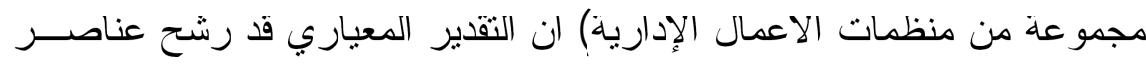

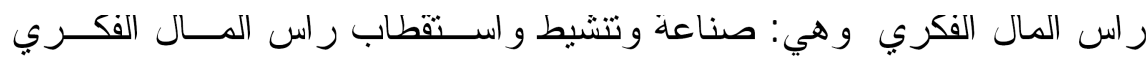

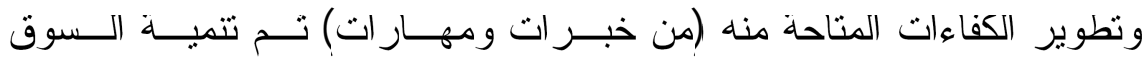

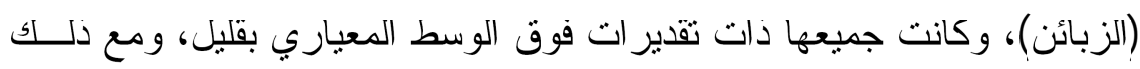
فقد كانت مرتبطة ايجابيا ومعنويا بعناصر نظام معلومات الموارد البشرية.

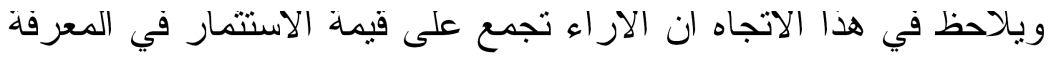

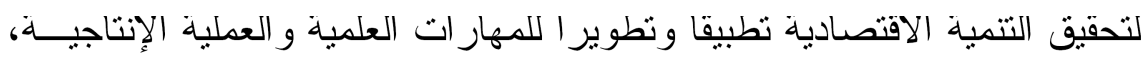


نم الاستتمار في (ب وت) من اجل خلق قاعدة علمية اساسية لتحقبــن عو ائــــ هامة من الإنتاجية. وفي كلا المحورين نركيز على الاستتمار في راس المــال البشري دعامة النتمبة و النطوير الرئيسة.

بعدها ركزت در اسة كريلّخ مع جوركنسون بعنو ان "راس المال مصدر ا

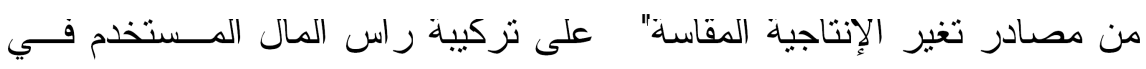

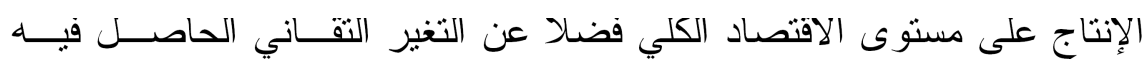
بوصفه مصدر التغير الإنتاجية المقاسة في الاقتصاد الامريكي. وقد قدر الغطـ إنط

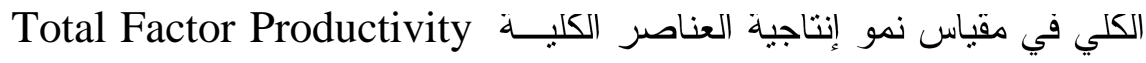
(TFP) يأتي: (14\%) اخطاء في فياس اسعار السلع الاستثمارية (23\%) اخطاء تجميع

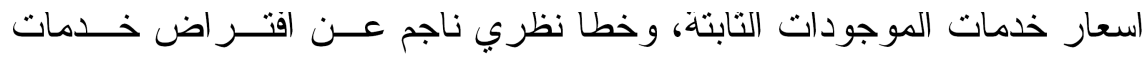
راس المال منسوبة إلى رصبد راس المال نفسه بنحو (45\%). ويعـدَّان ذلــك مغالاة في شرح الباهي الذي اطلق عليه كريـخ: مفيـاس جهانــــ (او إهمالنــا)

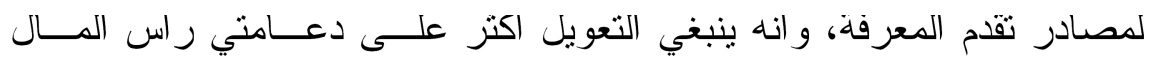
البشري وغير البشري في شرح النمو الاقتصادي.

وفي در اسة اخرى للاقتصادي ترلك؟1 يصر ح باحتمالية ضخامة الاتــار

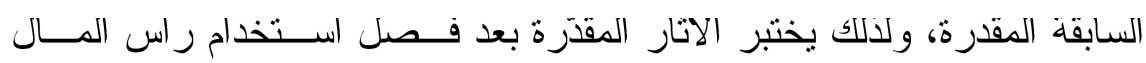
البشري المنز ايد بوصفه احد عناصر التغير التقني. بعبارة اخرى بقــدر اتــار تتامي راس المال البشري على معدلات الثقدم التكنولوجي.

ويضيف انه إذا كانت الكلف الاساسية لانشطة (ب وت) قد نم تــضمينها في كلف العمل وراس المال فان كلفة راس المال البشري (H/C) لم تحت لـسب لاسته 


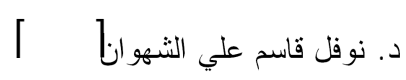
معلومات الانشطة الإبداعية وتقدير .ج

معها. ونظر ا لانعدام وجود مقاييس مباشرة فيجري قياس (H/C) بصورة غير مباشرة وبمتغبر ات تقريبية كما ذكر في اعلاه. ومع ان إدخال المتغير (H/C) وكتافته في الصبغة المختزلة لدالة إنتـــاج (كوب--دوكلاس) المقيدة لم يغير النتائج السابقة، يرجع ترلك السبب في ذلك إلى توصيف وقياس راس المال البشري نفسه (مقياس قيمة السوق للاجر الحقية لئي

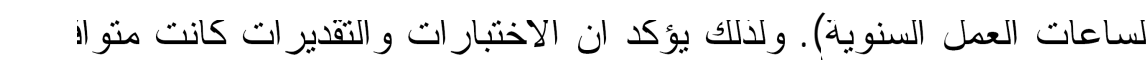

مع النتائج السابقة، و المطلوب بحث تقصيلي اكتر لتقييم اتار المدخلات غيـر المقاسة سابقا. و وان اتار (ب وت) كانت ضمن تقدير ات در اسة سابقة له.

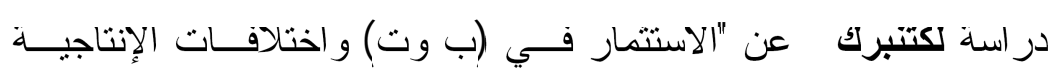
عالميا" تتوسع في إطار تحليلها لاتر الاستمار في (ب وت) على نمو الإنتاجية

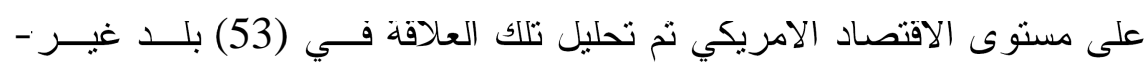
نفطي و غير مخطط مركزيا للمدة بين (1964) الى (1989). وقد اســتخدمت

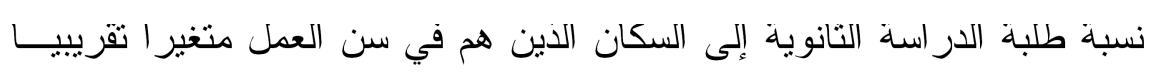
عن الاستتمار الصافي في راس المال البشري.

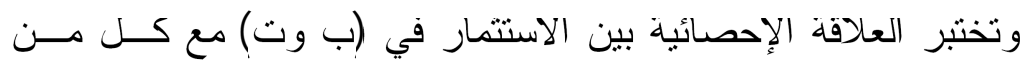

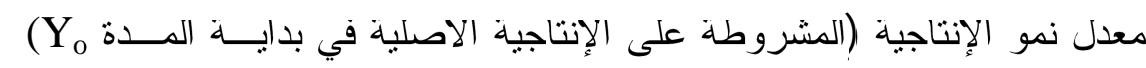

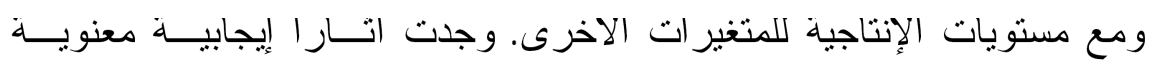
للاستتمار في (ب وت) خاص التمويل (SPR) على كلا المستو يين، وهذه الاتار

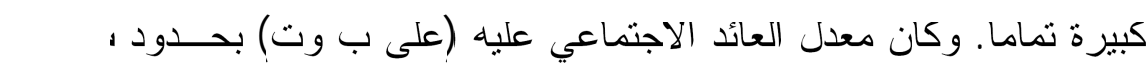

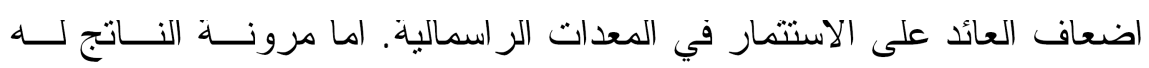
فكانت (0.077) ومقدار (0.183) المرونة لر اس المال الطبيعـي (S. معادلة الإنتاجية (y=Y/L): 


$$
\ln \mathrm{y}=\alpha_{\mathrm{o}}+0.321 \ln \left(\mathrm{S}_{\mathrm{H}}\right)+0.183 \ln \left(\mathrm{S}_{\mathrm{K}}\right)+0.077 \ln \left(\mathrm{S}_{\mathrm{PR}}\right)-0.971 \ln \left(\mathrm{S}_{\mathrm{GR}}\right)
$$

(2.96)

$$
\text { اما معادلة نمو الإنتاجية فكانت مروناتها مع التناثر ات (S) }
$$$$
\ln y_{\mathrm{t}}-\ln y_{\mathrm{o}}=\beta_{\mathrm{o}}+0.258 \ln \left(\mathrm{S}_{\mathrm{H}}\right)+0.357 \ln \left(\mathrm{S}_{\mathrm{K}}\right)+0.062 \ln \left(\mathrm{S}_{\mathrm{R}}\right)
$$

$$
\begin{aligned}
& -0.971 \ln \left(\mathrm{S}_{\mathrm{GR}}\right)+0.021 \ln \left(\mathrm{S}_{\mathrm{SO}}\right) \\
& \text { (-38.84) }
\end{aligned}
$$

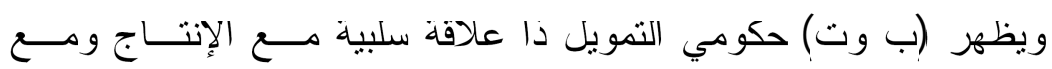
الإنتاجية مشير ا إلى ان البلدان ذات نسبة الانفاق الحكومي من الـــدخل القــومي الإجمالي (GNP) الاعلى على (ب وت) لها نمو إنتاجية اقل. ونؤكد الدراســـة

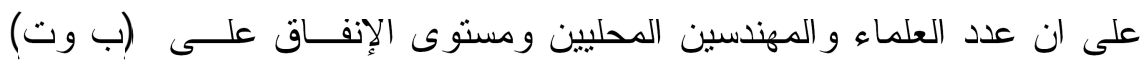
محددين هامين معنويا لمستوى دخل البلد، و ان البلدان ذات النــــــ الر اســــالي الاعلى لها نمو إنتاجية اعلى.

ويقدم الباحث زنك ·r في اطروحته للدكتور اه تحت عنو ان "در اسات فـي

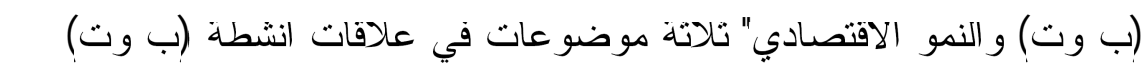

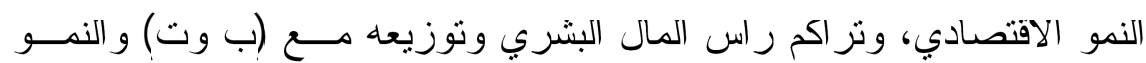
الاقتصادي بالرفاه.

يركز الموضوع الاول على "التـــر اكم الر اســــالي و (ب وت) و النمـــو

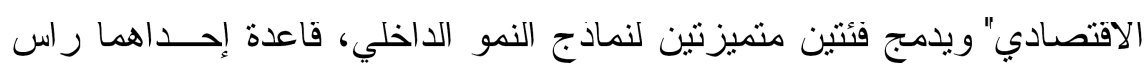
المال وقاعدة الاخرى فكرية. ومع تطوير توازن دينــاميكي عام يتحــد فيـهـ تز اكم راس المال الطبيعي و البشري و الاستثمار في(ب وت) داخليا يبين ان كلا من سياسة تو ازن عدم-التنخل ومعدلات النمو المتلى تعتمد طرديا على: كفــاءة 
] معلومات الانثطة الإبداعبة وتقدير.

تز اكم راس المال البشري؛ وحجم الاقتصاد؛ و إنتاجيــة (ب وت) ؛ وحجــم (او

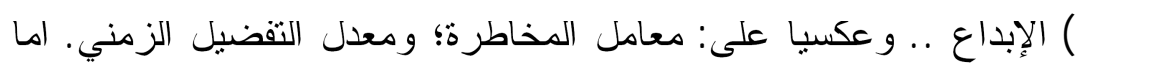
قوة الاحتكار فلا نؤتز على معدل النمو الامتل و إنما تميل لتزيد من حالة عــدم التنخل. وتحت هذه الحالة قد يكون معدل النمو الفعلي اعلى او ادنى هن النمــو الامنل، و هناك دوما نظام للضريبة/للاعم لتحقيق النمو الامتل.

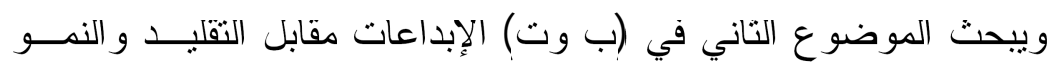
الاقتصادي ويركز على الخصائص التوزيعية لر اس المــال البـشري. ويقــدم نمودجا يمكن ان تحدث فيه الإبداعات و التقليدات في القطاع ذاته و الوقت نفسه.

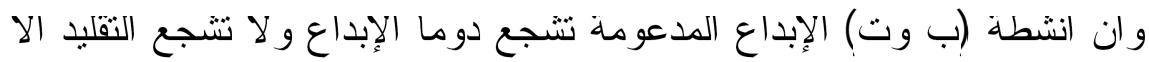
إذا كان الاستخدام الفعال لانشطة الإبداعات مرتفع كثير ا قياسا مـــع الاســتخدام

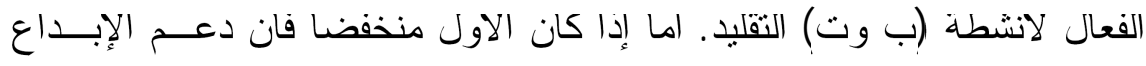

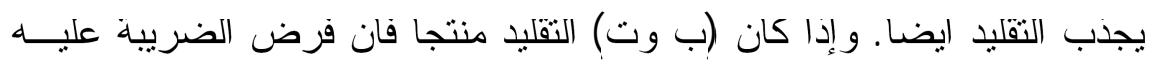

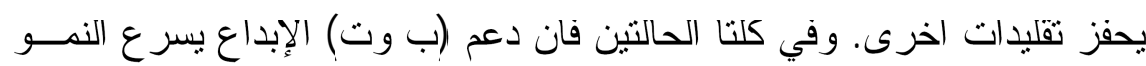
الاقتصادي دائما في حين دعم الاخر يفعل العكس فضـال عـن ان اتـــر كـلا الدعمين على الرفاه غير و اضحة (Ambiguous). يتوسع الموضوع التالــث

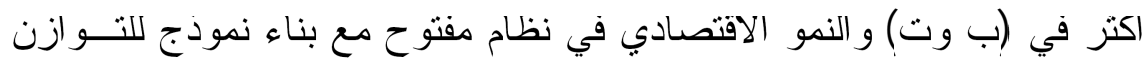

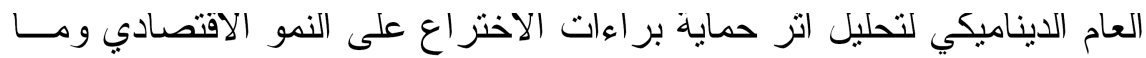
الى ذلك.

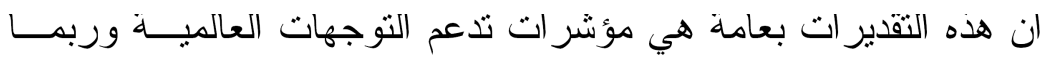
كانت مرثقعة نو عا ما ولكنها في الوقت ذاته تقع ضمن المديات الطبيعية التـي لتهي تطرحها النظرية الاقتصادية ونظريات تطور المنظمة بشكل عام، رغم ان هناك من بيين ان تلك الإسهامات المقدرة هي صغيرة اصلا حتى على مستوى بعض 
البيئات المتقدمة'ب. فهل هناك ما بدعم منل هذه التوجهات محليا؛ في الاســطر

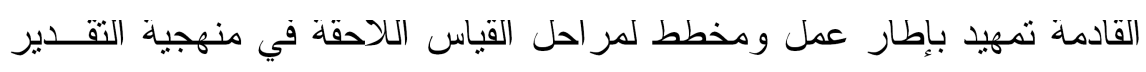
التجريبي لدور الإبداعات الصناعية المحلية في الثقــدم النكنولــوجي المحلــي المنو اضع.

r - معلومات الإبداعات وتقدير تطور المنظمه

يتعامل هذا المبحث مع نظام المعلومات المحلي السائد، و الذي يمكــن ان

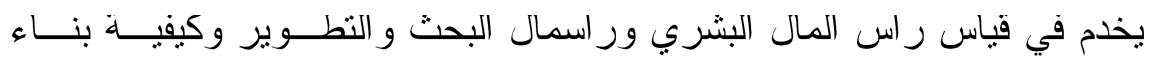
سلاسل كل منهما وقباس معدلات التقدم التكنولوجي وذلك على مستوى منظمـــة

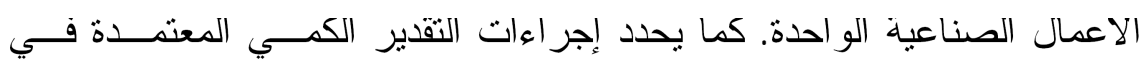
اختبار نظم المعلومات المتاحة ودور ها في در اسة مصادر التطور المفترضدة.

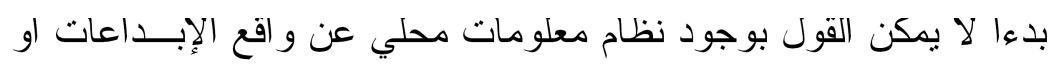
عن تعاريف محددة لها قابل للاعتماد وكذلك عن مقاييس معينة لـــر اس المــال البشري على المستوى الكلي او القطاعي في العراق (كما هو الحال في اغلــبـ

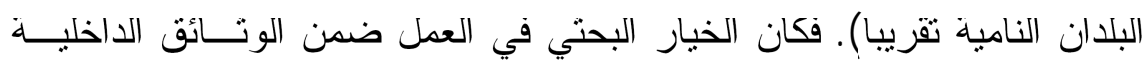
لانشطة الإنتاج وما يتصل به من حسابات وتكاليف وذلك على مستوى منظمــة الاعمال الصناعبة الو احدة. وقد جرى البحث و الإطلاع الميداني على الواقــع الموتـق لمعلومــات

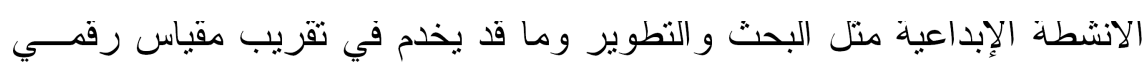
لمفهوم راس المال البشري، وذلك في اهم الصناعات العريقة (في الموصــل). و من خلال وتائق الحسابات الختامية نزكز العمل في صناعتين تحويليتين وتثالتة

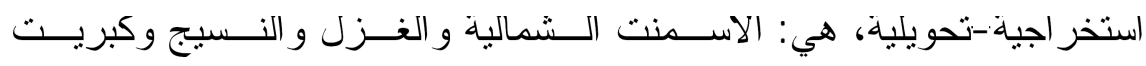




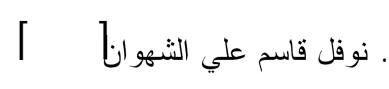
معلومات الانثطة الإبداعية ونقير.

المثُر اق.وتم اقتباس ارقام العناصر الحساباتية لكل من مقيــاس راس المــال

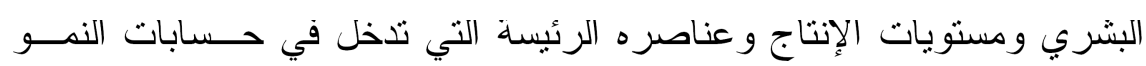
الاقتصادي ومقياس التغير التكنولوجي لكل منظمة على حدة.

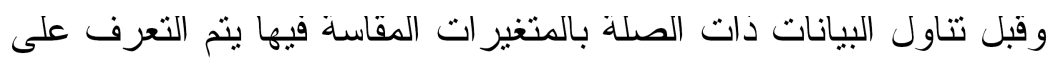

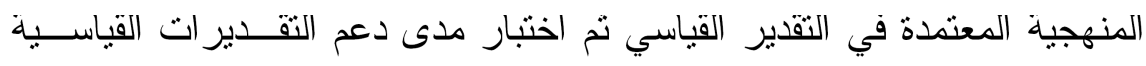

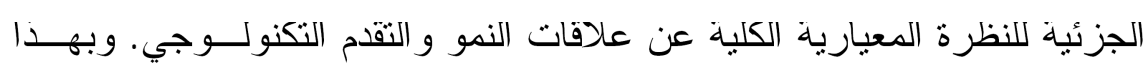

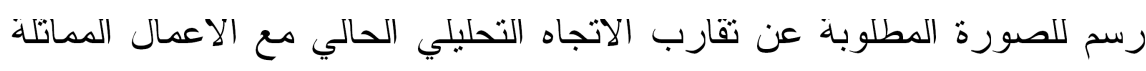

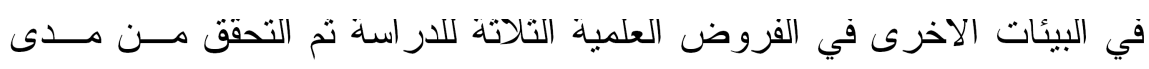

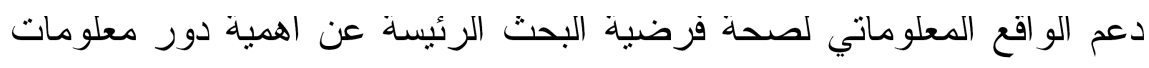
الانثطة الإبداعية في تقدير مصادر التطور النكنولوجي.

r - المنهجيه

بافتز اض ان المنظمة تعمل بدالة للإنتاج (Q) بثلاثة عناصر إنتاج هما:

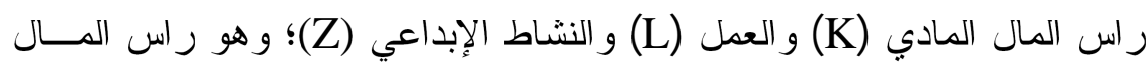

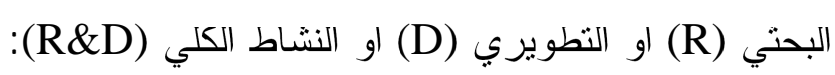
$Q_{i}=\mathrm{A}_{i} f(K i, L i, Z i)$

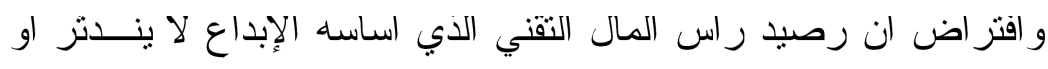

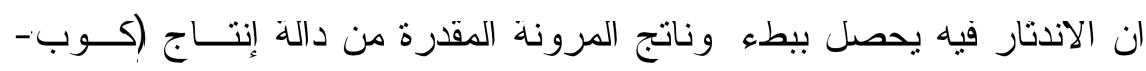

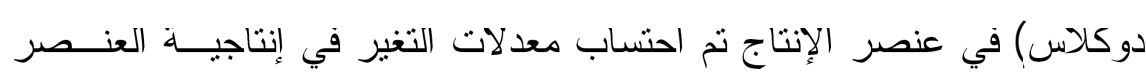

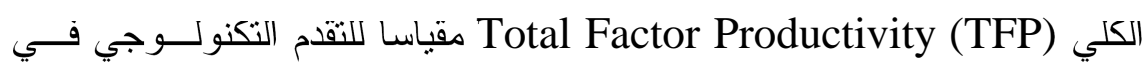
المنظمة rr. 


$$
\begin{aligned}
& \text { و افترضت الدر اسة، على مستوى المنظمة الو احدة ان اهـــ المتغيـر ات } \\
& \text { الإبداعية المؤتزة في نمو العنصر الكلي التكنولوجي هما تــر اكم راس المـــال } \\
& \text { البشري ورصيد راس مال البحث و /او النطوير المحليين: } \\
& (\mathrm{TFP})_{\mathrm{i}, \mathrm{o}}=\lambda_{1,0}+\lambda_{2}(\dot{\mathrm{H}})_{\mathrm{i}, \mathrm{o}}+\lambda_{3}(\mathrm{R})_{\mathrm{i}, \mathrm{o}}+\xi_{\mathrm{i}, \mathrm{o}} \\
& \text { إذ ان: } \\
& \text { (TFP) : معدلات الثقدم النكنولوجي (tfp /tfp) المقــاس للفتـرة (i) ف في } \\
& \text { المنظمة (o) . } \\
& \text { بعناصر الإنتاج. } \\
& \text { المقاس على النزتيب. }
\end{aligned}
$$

معدلات التز اكم في رصبد راس المال البشري (H/C) مقلسة بـ ششكل (H) منك

$$
\cdot(\dot{h} / h)
$$

: معدلات الزيادة في راس مال النشاط الإبداعي ؛؛ الابحـــاث النطبيقيـــة (R)

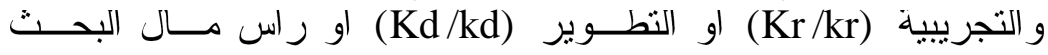

$$
\text { و النطوير الكلي (kr \& d /kr \& d) . }
$$

(o) : العنصر العشو ائي في مكونات النقدم النكنولوجي المقاس في المنظمة

$$
\text { في الفنرة (i) (1) }
$$




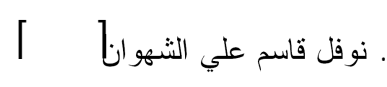

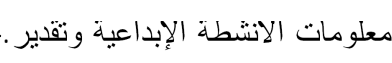

وهناك مصدر اخر يفترض به الإسهام في رس مال المعرفة في المنظمة وهو

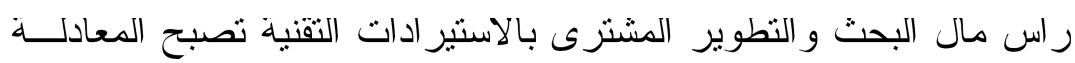

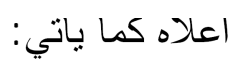

$$
(\mathrm{TFP})_{\mathrm{i}, \mathrm{o}}=\lambda_{1, \mathrm{o}}+\lambda_{2}(\dot{\mathrm{H}})_{\mathrm{i}, \mathrm{o}}+\lambda_{3}(\dot{\mathrm{R}})_{\mathrm{i}, \mathrm{o}}+\lambda_{4}(\dot{\mathrm{T}})_{\mathrm{i}, \mathrm{o}}+\xi_{\mathrm{i}, \mathrm{o}}
$$

(T) : معدلات النمو في راس مال البحث و النطوير الأجنبي المستشترى بـشكل

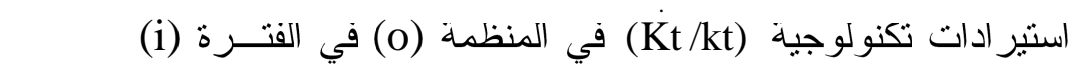

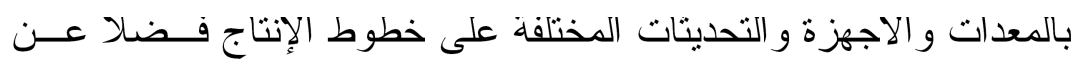

$$
\text { العدد و المسنتزمات المتجددة على تكنولوجيا الإنتاج. }
$$

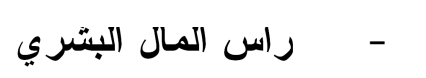

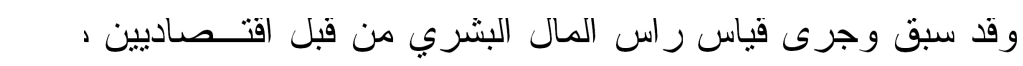

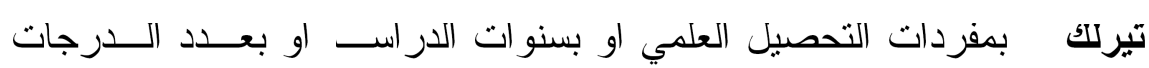

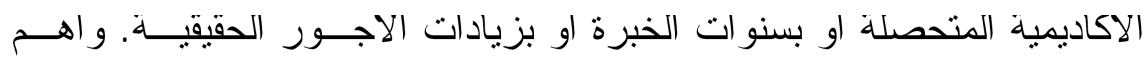
الملاحظات على الدراسات السابقة هي ان إدخال متغير (نسبة او كتافة استتمار) راس المال البشري، لم يغير النقدير ات السابقة للعو ائد على الإبداع.

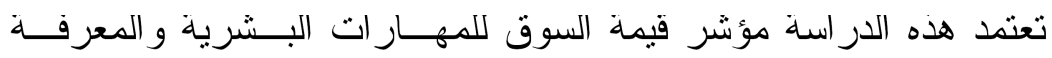

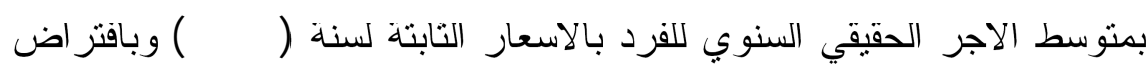
ان صافي الزيادة (او النقصان) في الرصيد خلال الفترة (i) تساوي الاســتنمار

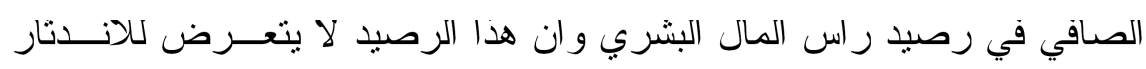
$:(\delta=0)$ 
وينت بناء سلاسل لازصدة راس المال البـشّري (H/C) و ر اس المــال

$$
\text { البحتي؛ المحلي (R)؛ و المستورد (T) وفق الصناء سنيغة: }
$$

$X(t)=\left(1-\delta_{x}\right) X(t-1)+I_{x}(t)$

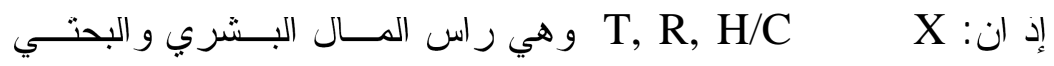

المحلي و المستورد على التزتيب.

اي ان الدراسة الحالية ثقترح توصيف دور راس المال البشري بـ بشكل

مشترك مع المتغير ات التكنولوجية الرئيسة منل الانشطة الإبداعية المحلية (R)

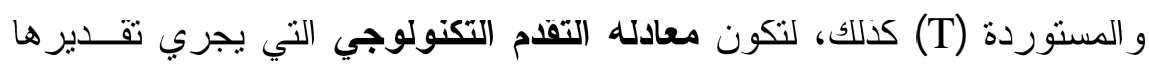
في الصناعات النلاث بالشكل النالي:

$T \dot{F} P=\hat{\epsilon}_{1}+\hat{\rho}(\dot{R} / R)+\hat{\phi}(\dot{T} / T)+\hat{\zeta}(\dot{H} / H)$

\section{r r - معدلات العائد من التقلم التكنولوجي على الانتطه الإبداعيه}

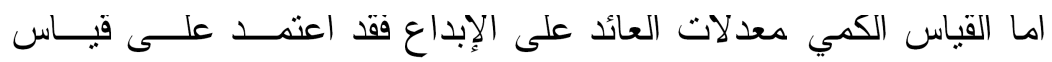

سلاسل راسمال الإبداع على انه مجموع مرجح للانفاقات السابقة على الإبــــاع وباوزان او نرجيحات تعكس كل التباطؤات المحتملة في تاتير ذلك الإبداع على الناتج، وتعكس اندتاره المحتمل في الوقت نفسه، طالما لا تتوفر اية معلومسـات

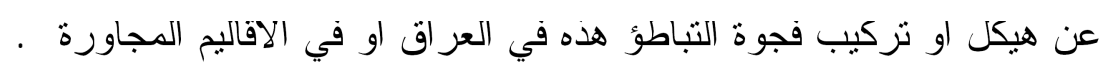

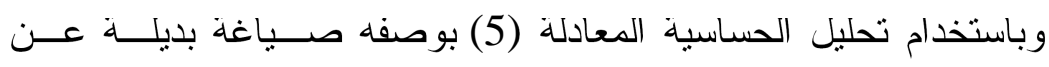

مستويات قيم المتغير ات الاقتصادية الني يتضمنها النمــودج، ودلــك بـــاجر اء

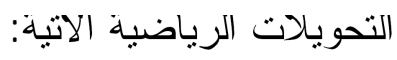

$(\mathrm{d} l n \mathrm{Q}) / \mathrm{dt} \mathrm{A}+\mathrm{B}(\mathrm{d} \operatorname{lnX}) / \mathrm{dt}+\theta_{1}(H / Q)+\theta_{2}(\mathrm{R} / \mathrm{Q})+\theta_{3}(T / Q)+\mathrm{du} / \mathrm{d} 1 \ldots(6)$ 
$\mathrm{TFP}(\mathrm{dlogQ}) / \mathrm{dtB}(\mathrm{d} \ln \mathrm{X}) \neq \mathrm{A}+\theta_{1}\left(H / Q+\theta_{2}(\mathrm{R} / \mathrm{Q}) \theta_{3}(T / Q+\mathrm{u}\right.$ ((dln KR)/dt) ) تم تبسيطه بالاستفادة من تعريف معدل العائد:

$\theta=\mathrm{dQ} / \mathrm{dKR}=\gamma(\mathrm{Q} / \mathrm{R})$

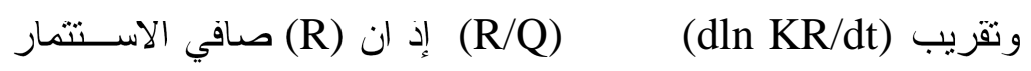

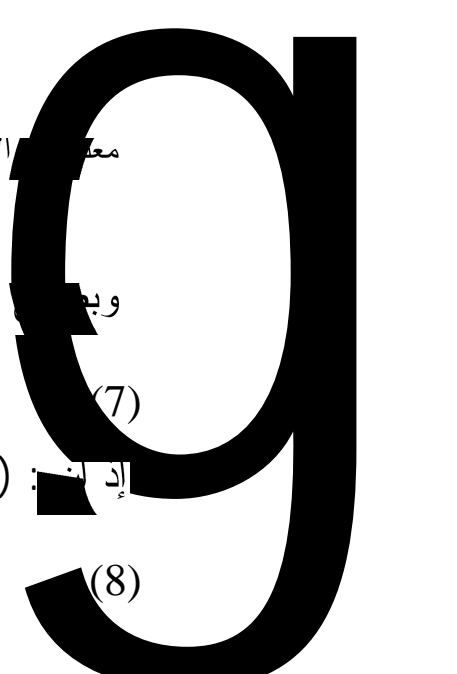

في راسمال الإبداع البحتي. اي صافي من الاندثار الممكن في راسمال الإبـــاع

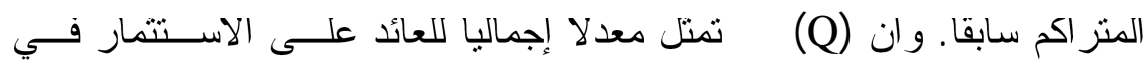
(KR)، و إجمالي الاندتار و التقادم (للتقصيل بلاحظ الملحق - (1).

وبذلك فان معدلات التقدم التكنولوجي المقاس قد ارتبطت بكتافة (R/Q) و (T/Q) للاستتمار في الإبداع وكـذلك بكتافــة (H/Q)، وبمقيــاس اثـــمل

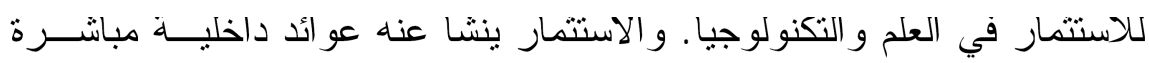
يجري تقدير ها بمعادله العو ائد بالشكل الاتي:

$T \dot{F} P=\hat{\epsilon}_{2}+\hat{\theta}_{1}(\dot{R} / Q)+\hat{\theta}_{2}(\dot{T} / Q)+\hat{\theta}_{3}(\dot{H} / Q)$

ويبين مجموع (H/H

الإبداع المحلي و المشتزى، في حين ان رصيد راس المال البشري من التقدم التكنولوجي.

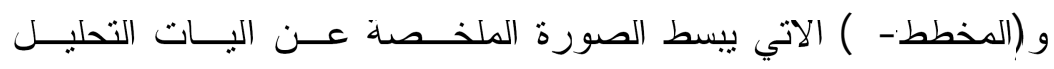

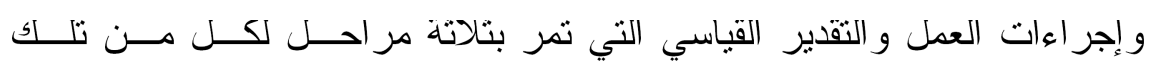

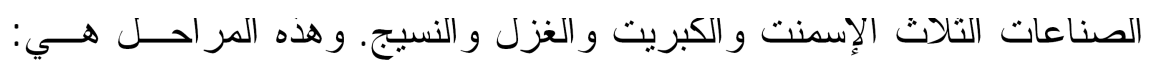

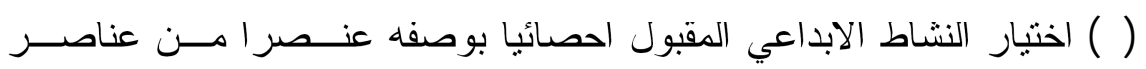

الانتاج؛ (Y) تقدير دور النشاط الابداعي المقترح الى جانب نز اكم راس المـــال 
البشري و (ب وت) المستورد مصدر ا للنطور التكنولوجي؛ (ب) تقـدير العوائــــ من التقدم النكنولوجي على كل من ثلك المصادر .

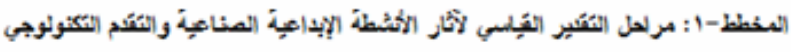

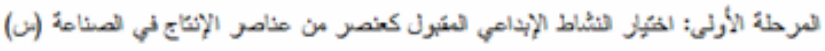

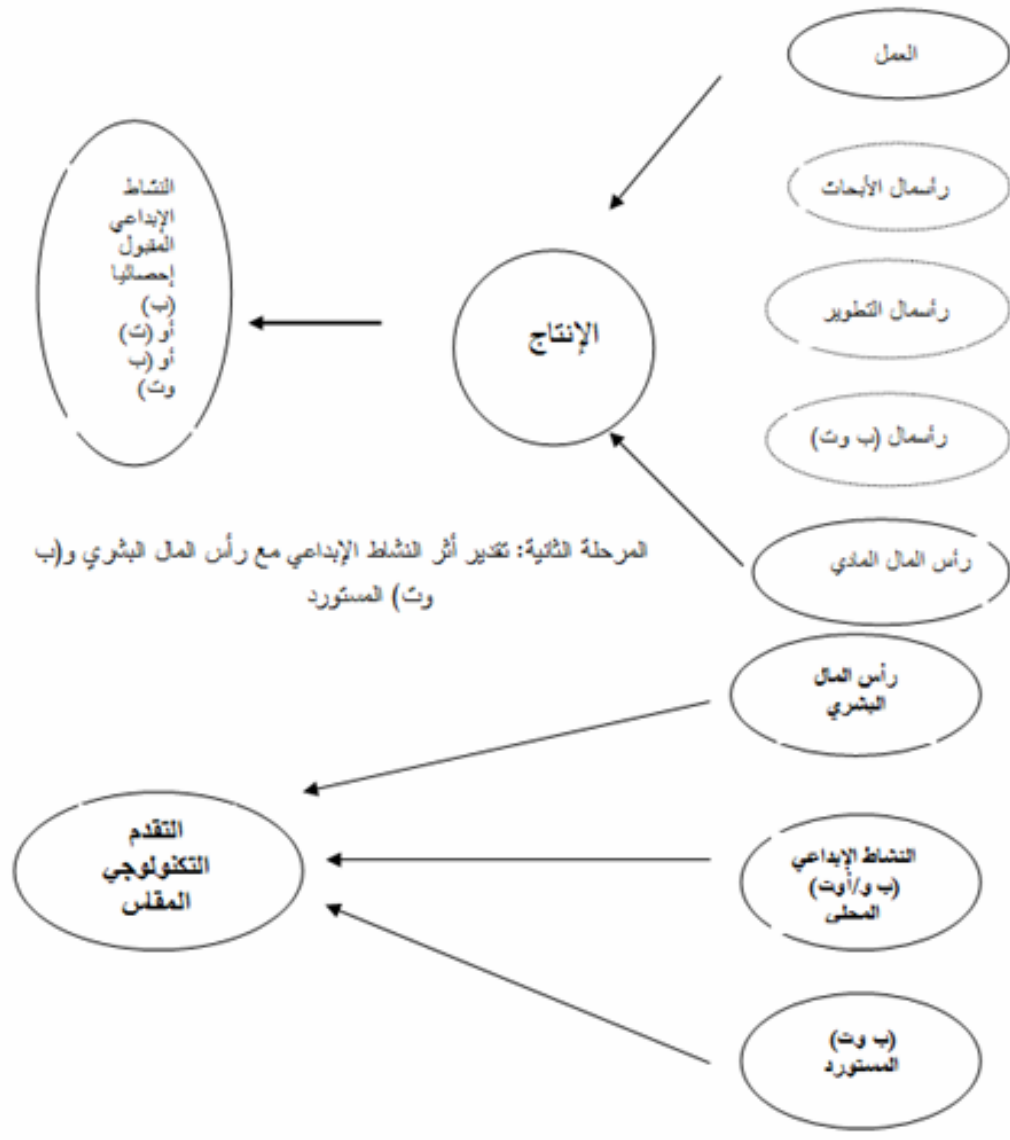
الع

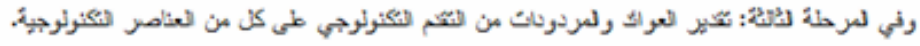




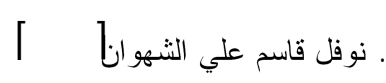
معلومات الانثطة الإبداعية وتقدير.

\section{ع - تفدير دور الإبداعات في التفلم التكنولوجي الصناعي}

اصبحت المعرفة مصدر ثروة ومؤشر قوة، لبس فقط عبر تحويل بعـض لإن

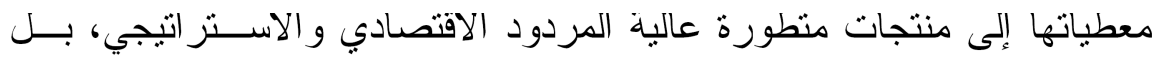

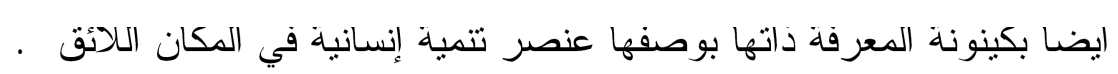
فإذا كان "الإبداع مورد قيم ومهم ينبغي تعزيزه وتطوبره و وعدم الـسماح بهدره في ضوء التكاليف العالبة المرتبطة بالمو اهب المبدعـــة و البنيــة التحتيــــة

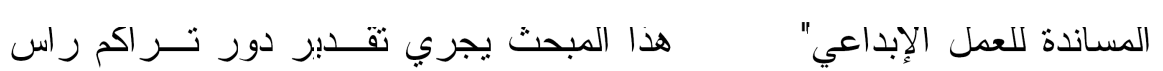

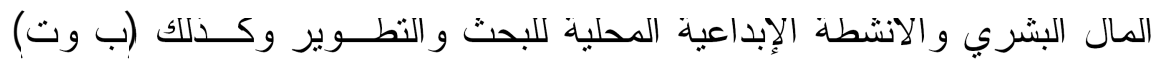
المستورد في كل من صناعة الاسمنت و الكبريت و الغزل و النسيج علــى النقــدم

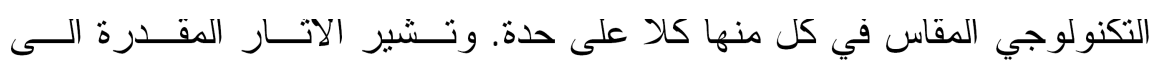
الاسهامات في التقدم لكل من تلك العناصر وكذلك الى العو ائد التي تحققها منه.

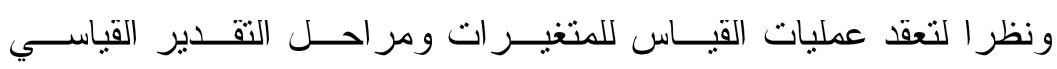

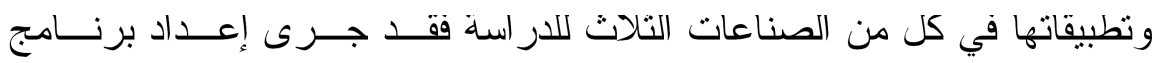
حاسوبي جاهز يكتقي باستخدام برمجيتين (الملحق -س) لغرض التقدير و الحصول

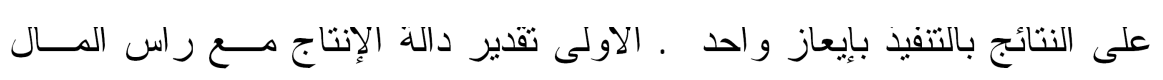

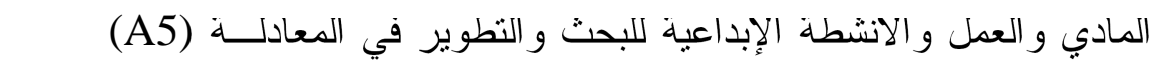

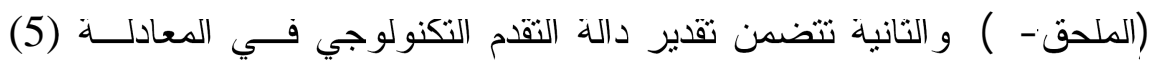
و تقدير معدلات العو ائد في المعادلة (9).

ع - اتقدير اتار الاتشطه الإباعيه على التقام التكنولوجي في صناعه الاسمنت

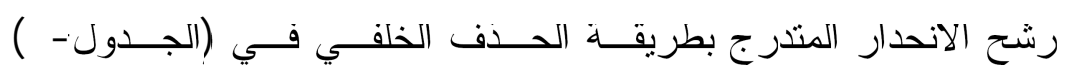

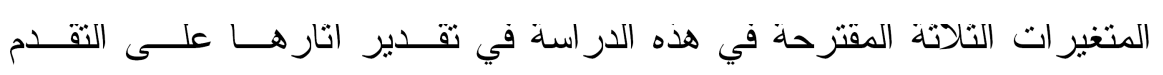


التكنولوجي المقاس وذلك في صناعة الاسمنت الشمالية. في الانحدار الاول فقط راس المال البشري لله اتار ايجابية بخلاف المتغيرين الاخرين، وجميعها غيـــر

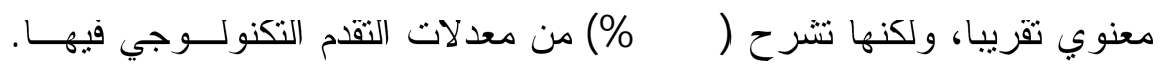
وفي الخطوة الثانية اختفى تاثير البحث و التطوير المستورد نم اختقى في التالتـــة راسمال البحث و النطوير المحلي ليبقى تز اكم راس المال البشري لوحده شــارحا

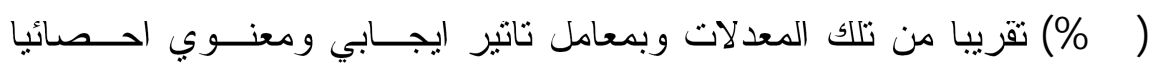
[ تضاعف نز اكم راس المال البشري بسهم في تسريع معدلات التقام التكنولــوجي

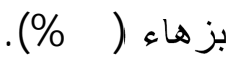
إن هذه الاتار المقدرة تدعم الفروض العلمية لهذه الدر اسة على الرغم من إنها دون التقدير ات العالمية المماتلكة، خاصدة إذا علمنا ان رصـــبد راس المـــال البشري المقاس في صناعة الاسمنت قد نر اكم بمعدل يفوف خمسة اضعاف معدل

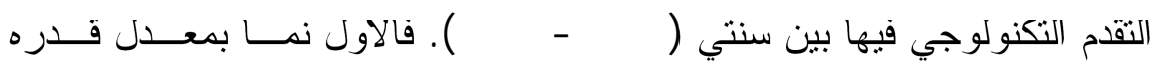

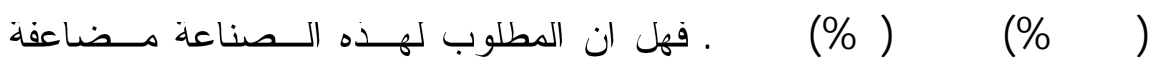

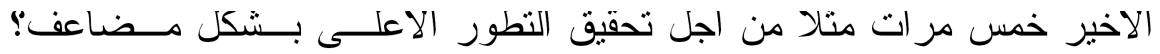
الإجابة طبيعبا بالنفي، وذلك لان العمل على مضاعفة رصيد راس المال البشري

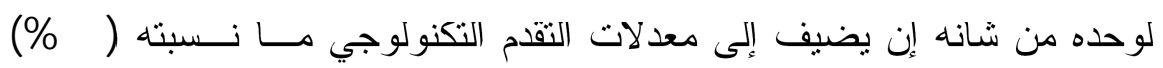
حسب التقدير اعلاه، وهذا ما قد يتجاوز في هــــه الحالـــة التقــدير ات العــالمي المماتلة. ان هذا الاتجاه التحليلي يفترض اساسا صحة المعلومات الموتقـــة ودقــــة البيانات المعتمدة في قياس تلكك المتغير ات. ومع هذا فان ايــا مــن راس المـــال البشري او المتغيرين الاخرين لم يحقق عو ائد ايجابية ذات دلالة احصائية مسن 
] معلومات الانشطة الإبداعية و تقدير .

معدلات التقام التكنولوجي المقاس (الجدول-Y). و هذا يعني، من بين المضامين

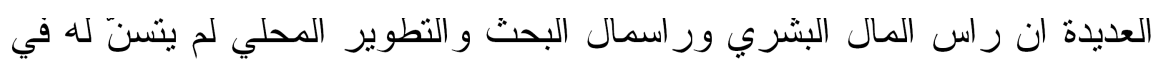

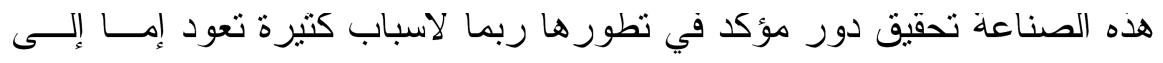

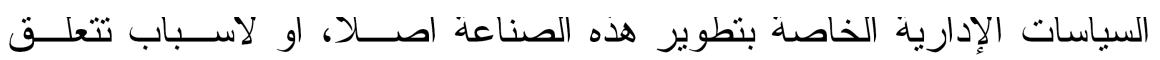
بطبيعة البيانات ومحدودية المعلومات اللازمة في تمتيل المتغير ات الإدارية.

ع r تفير اتار الاتثطه الإبداعيه على التفام التكنولوجي في صناعه الكبريت تبدو الصورة العامة لاتجاهات النقدير في هذه الصناعة افضل من سابقتها

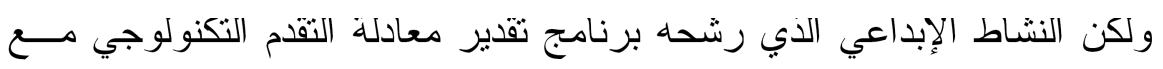

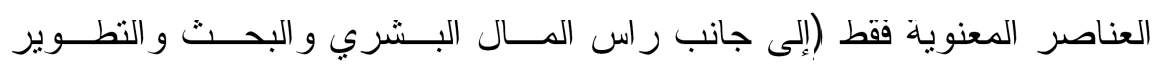

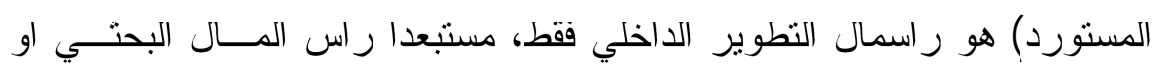
راسمال البحث و النطوير الكلي.

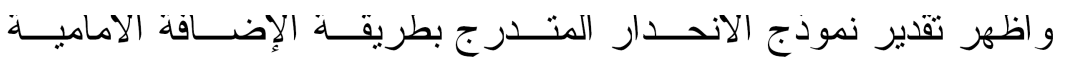

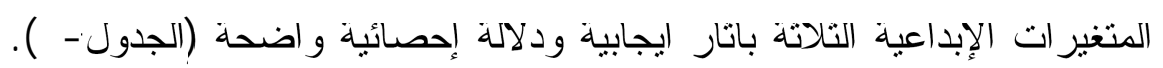

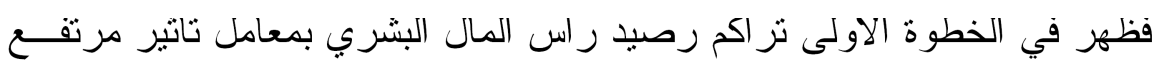
تماما: [ (2.70)

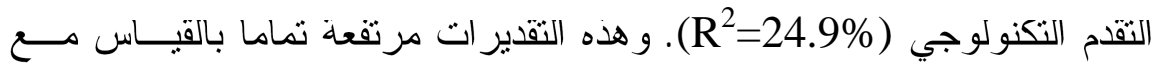

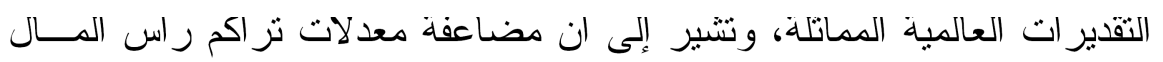

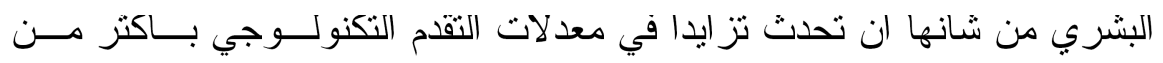
ضعفين في الصناعة الكبريتية.

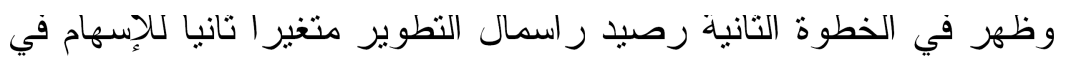

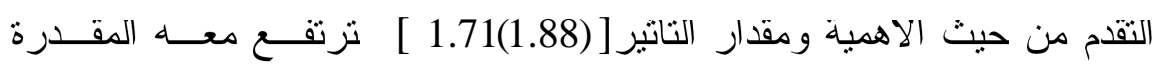
التوضيحية إلى (35.6\%). وفي الانحدار النالث ظهر البحث و التظوير المجسد 


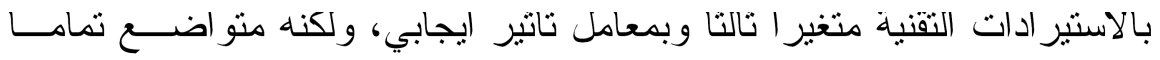

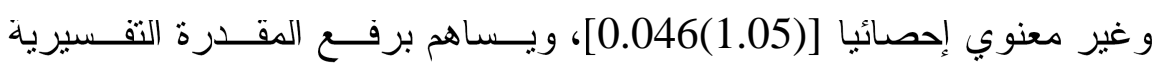
للنمودج بقدر محدود لم يتجاوز عندها (39\%). و الملفت للنظر ان ايا من تلك المتغير ات لم يحقق عو ائد داخلية مهمة من

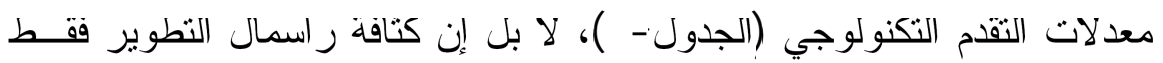
هي الني ظهرت بعلاقة ايجابية في حين ارتبطت كل مــن كتافــة راس المــال البشري وكتافة راسمال البحث و النطوير المستورد بعلاقة سلبية، وان المتغيرات

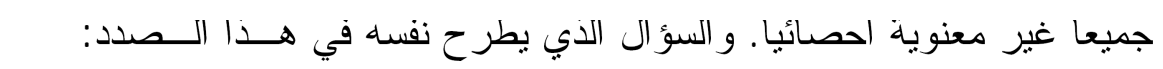
تقسير اللاستقر ارية في التقديرات المنتاظرة في اعلاه بين الاتار و العو ائد (ف مي

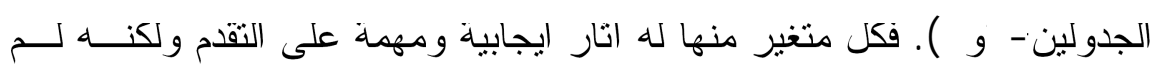

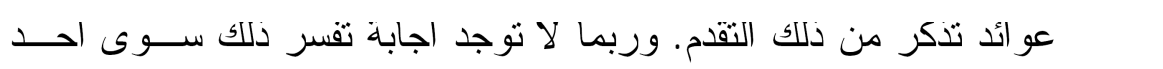

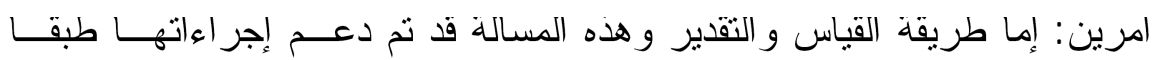
للطرق العلمية السائدة على المستوى العالمي، وكما مر في المبحــث الـــابق؛ و الامر التناني مردَه ان نظم المعلومات عن هذه الانشطة الإبداعبة وكذلك الارقام و البيانات الخاصة بها ليست بالمستوى المطلوب من حيث الكفاءة في النوتيق او الدقة في التبويب فضلا عن اوجه الإنفاق و الاستتمار في كل من تلك الانشطة.

ع - r تقدير اتار الاتشطه الإبداعيه على التقلم التكنولوجي في صناعه الغزل والنسيج

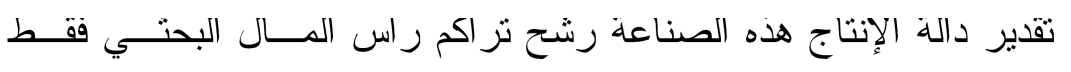

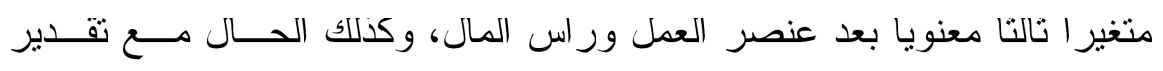

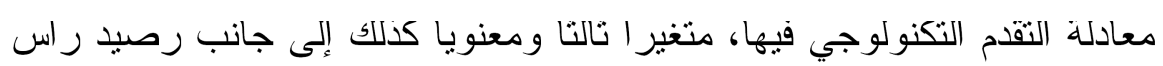
المال البشري وصبد راسمال البحث و النطوبر المسنورد. 


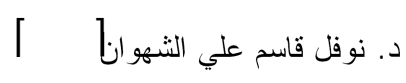

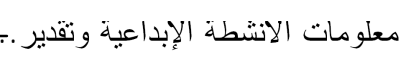

و الملاحظ ان هذه الصناعة (الغزل و النسيج الحكومية في الموصل) هـ مي

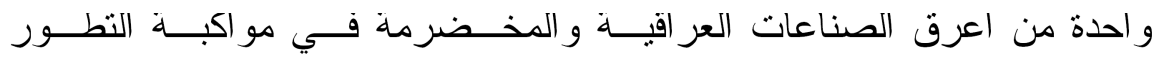

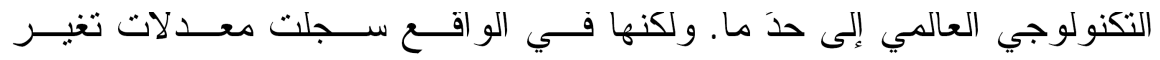

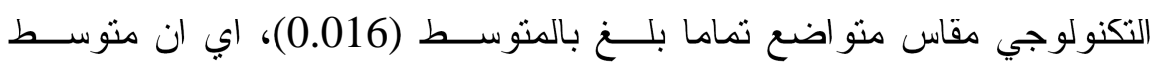

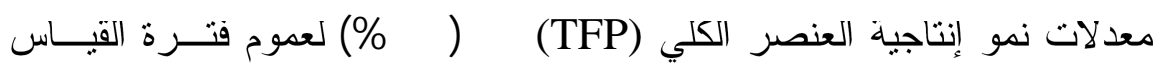

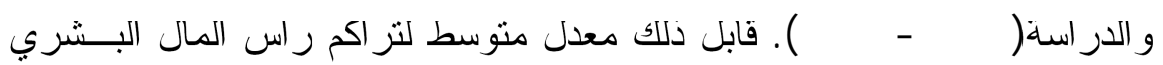

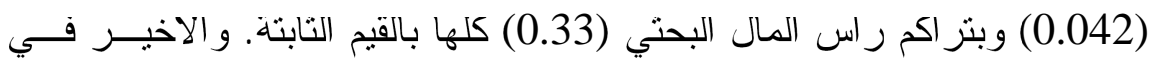

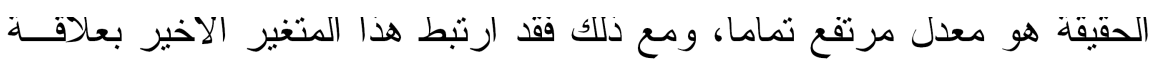
التاتير السالبة وغير معنوية مع التكنولوجيا كما سيلاحظ بعد قليل.

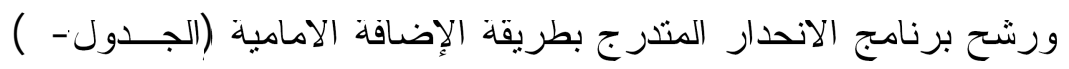

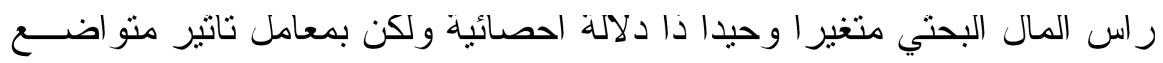

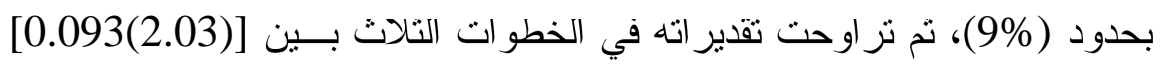

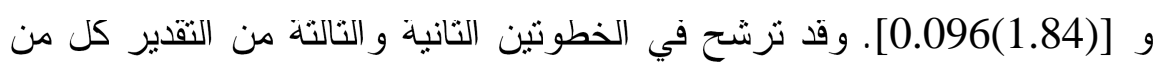

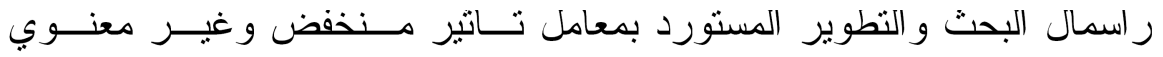

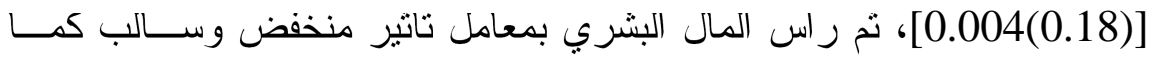

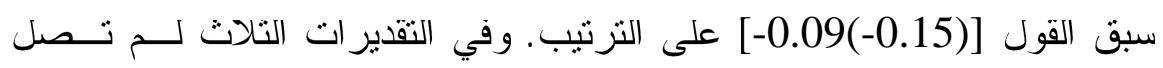

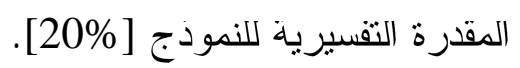

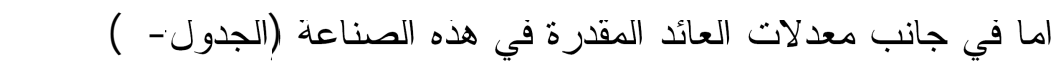

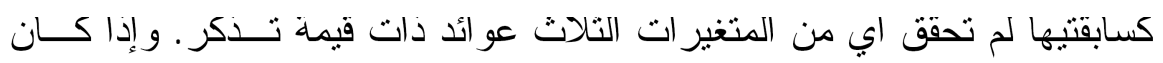

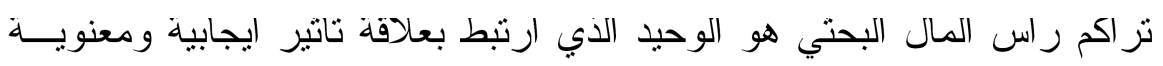

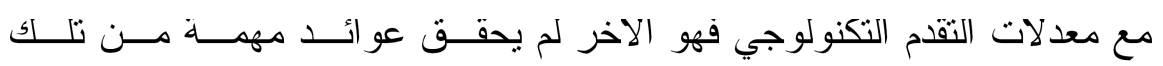
المعدلات. في حين سبق ولوحظ في المبحث الثناني السابق ان المعدلات المقدرة 


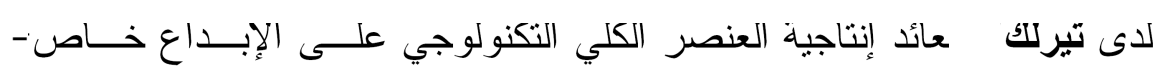

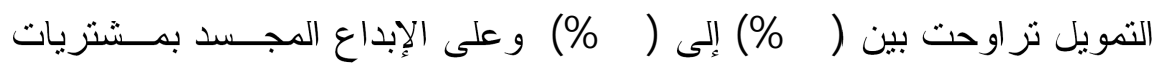

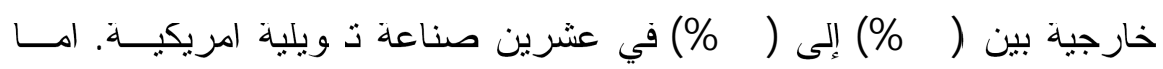

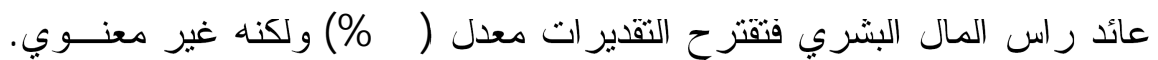
وكل هذه التقدير ات كانت اضعف عندما اضيفت تلاث عـشُرة صــناعة غيــر تحويلية معها، فضلا عن غياب اهمية الإبداع حكومي التمويل في كلبهما. الجدول - ا: اتار إب وت) المحلي المباشرة وغير المباشرة و إب وت) المثترى وراس

المال البشري على الإتتاجيه المقاسة في المنشاة العامه للاسمنت الشماليه

\begin{tabular}{|c|c|c|c|}
\hline Step-enter & $\mathbf{1}$ & $\mathbf{3}$ & $\mathbf{4}$ \\
\hline $\boldsymbol{\lambda}$ & 0.1003 & 0.0248 & 0.009 \\
\hline$\dot{\mathrm{K} r \& d} / \mathrm{Kr} \& \mathrm{~d}$ & -0.08 & -0.059 & \\
& $(-1.70)$ & $(-1.36)$ & \\
\hline$\dot{\mathrm{H}} / \mathrm{H}$ & 0.14 & 0.21 & 0.23 \\
\hline$\dot{\mathrm{t}} / \mathrm{t}$ & $(1.05)$ & $(1.76)$ & $(1.88)$ \\
\hline & -0.034 & & \\
\hline $\mathrm{S}$ & $(-0.90)$ & & \\
\hline $\mathrm{R}$ & & & 0.256 \\
\hline D.W. & 0.253 & 0.250 & $41.7 \%$ \\
\hline
\end{tabular}

$$
\text { بطريقة الحذف الخلفي للانحدار المندرج. }
$$

هذا التعارض في الاتار المقدرة محليا و عدم العتور على عو ائد تكنولوجية على راس المال البشري وحتى على الإبداعات المحلبة منها او المستوردة، كل دلك يبعث على النساؤل عن مدى دقة البيانات الموتقة في نظام معلومات الانشطة الإبداعية مع العناصر الداخلة في قياس التقام التكنولوجي في منل هذه الصناعات، وعن مدى الاهنمام بالجدوى الاقتصادية للاستثمار ، او حنى للإنفاق على تلك

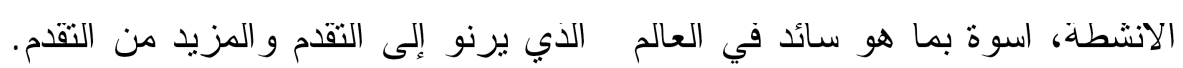




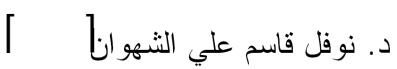
معلومات الانشطة الإبداعية و تقدير .7

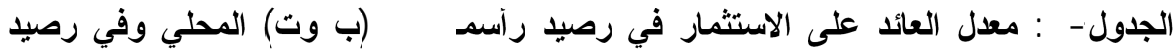

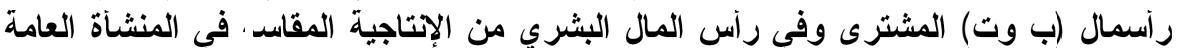

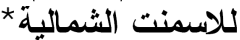

\begin{tabular}{|c|c|c|c|}
\hline Step-enter & $\mathbf{1}$ & $\mathbf{2}$ & $\mathbf{3}$ \\
\hline \hline $\mathrm{TFP} / \mathrm{TFP}$ & $\begin{array}{c}0.058 \\
(0.39)\end{array}$ & $\begin{array}{l}0.113 \\
(1.26)\end{array}$ & $\begin{array}{c}0.062 \\
(0.87)\end{array}$ \\
\hline$(\mathrm{Kr} \& \mathrm{~d} / \mathrm{va})_{\mathrm{t}}$ & $\begin{array}{c}-0.19 \\
(1.54)\end{array}$ & $\begin{array}{c}-0.19 \\
(1.65)\end{array}$ & $\begin{array}{c}-0.19 \\
(1.62)\end{array}$ \\
\hline$(\dot{\mathrm{t}} / \mathrm{va})$ & -0.0004 & -0.0003 & \\
$\mathrm{t}$ & $(-1.01)$ & $((-0.94)$ & \\
\hline$(\dot{\mathrm{H}} / \mathrm{va})_{\mathrm{t}}$ & -0.29 & & \\
\hline $\mathrm{S}$ & $(0.49)$ & & \\
\hline $\mathrm{R}^{2}$ & 0.315 & 0.308 & 0.307 \\
\hline $\mathrm{D} . W$. & $16.6 \%$ & $15.6 \%$ & $11.6 \%$ \\
\hline
\end{tabular}

* تشيح البرنامج للمتغير ات المعنوية احصائيا التقدير افضل نموذج، عند مسنوى معنوية (F=4.00) بطريقة الحذف الخلفي المندرج

الجدول -r: الاتار المباشرة لر اسمال التطوير الصناعي المحلي وأب وت) المشترى وراس المال البشري على الإتتاجيه المقاسة في المنشاة العامه لكبريت المشراق

\begin{tabular}{|c|c|c|c|}
\hline STtep-enter & $\overline{1}$ & $\overline{2}$ & $\overline{\overline{3}}$ \\
\hline$\lambda$ & $\begin{array}{l}0.048 \\
(0.17)\end{array}$ & $\begin{array}{l}0.126 \\
(0.47)\end{array}$ & $\begin{array}{l}0.018 \\
(0.06)\end{array}$ \\
\hline$(\mathrm{H} / \mathrm{H})_{\mathrm{t}}{ }^{*}$ & $\begin{array}{c}2.18 \\
(2.70)\end{array}$ & $\begin{array}{c}1.67 \\
(2.07)\end{array}$ & $\begin{array}{c}1.87 \\
(2.26)\end{array}$ \\
\hline$(\mathrm{K} \mathrm{d} / \mathrm{Kd})_{\mathrm{t}}$ & & $\begin{array}{l}1.170 \\
(1.88) \\
\end{array}$ & $\begin{array}{l}1.410 \\
(1.79) \\
\end{array}$ \\
\hline$(t / t)_{t}$ & & & $\begin{array}{l}0.046 \\
(1.05)\end{array}$ \\
\hline & & & \\
\hline $\bar{S}$ & 1.35 & 1.28 & 1.27 \\
\hline $\mathrm{R}^{2}$ & $24.9 \%$ & $35.6 \%$ & $39.0 \%$ \\
\hline D.W. & 2.66 & 2.74 & 2.65 \\
\hline
\end{tabular}

*الكتغبر الاول الذي رشحه برنامج الاندار المتدرج معنويا، وقد ادخل المتغير ان الاخر ان في النمونجين (2,3) بطريقة

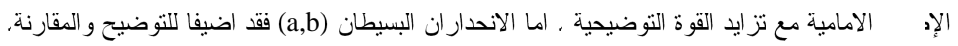




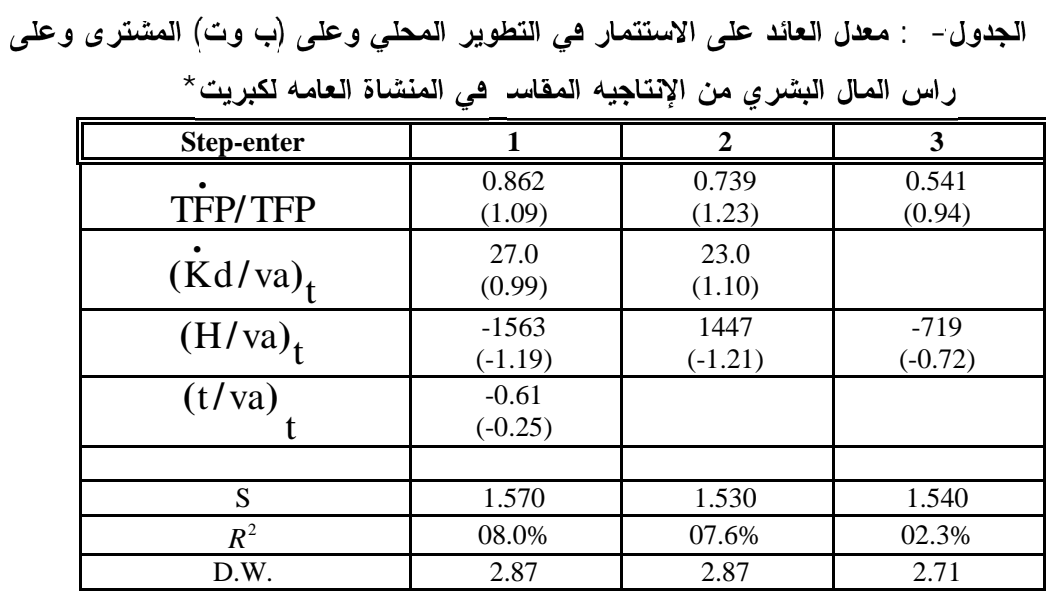

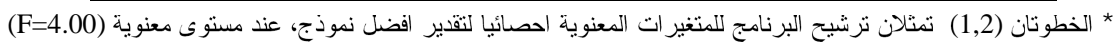

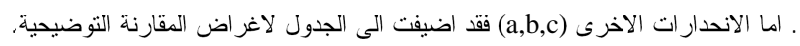

الجدول-0: الاتار المباشرة لر اسمال التطوير الصناعي المحلي وإب وت) المثترى وراس المال البثري على الاتتاجية المقاسة في المنشـاة العامه للغزل

$\left.\begin{array}{|c|c|c|c|}\hline \text { Step-enter } & \mathbf{1}^{*} & \mathbf{2} & \mathbf{3} \\ \hline \boldsymbol{\lambda} & -0.023 & -0.019 & -0.02 \\ (-0.32) & & (-0.29)\end{array}\right)$

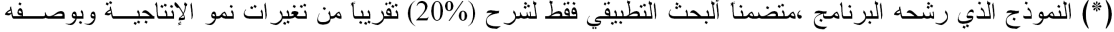

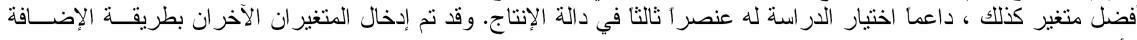

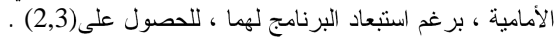




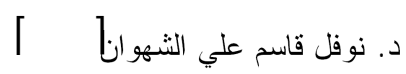
معلو مات الانشطة الإبداعية وتقدير .

الجدول-7: التقديرات المختلفه لمعلات العائد من نمو الإنتاجية على الاستتمار في كل من التطوير المحلي

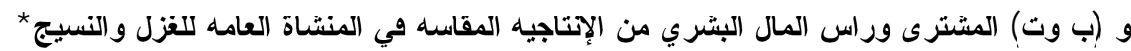

\begin{tabular}{|c|c|c|c|c|c|}
\hline Pr. Model & 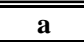 & b & $\bar{c}$ & $\overline{\mathrm{dd}}$ & e \\
\hline TंFP/TFP & $\begin{array}{l}0.039 \\
(0.05)\end{array}$ & $\begin{array}{l}0.190 \\
(1.00)\end{array}$ & $\begin{array}{l}0.083 \\
(1.00)\end{array}$ & $\begin{array}{l}-0.051 \\
(-0.55)\end{array}$ & $\begin{array}{l}0.177 \\
(0.76)\end{array}$ \\
\hline$(\mathrm{Kr} / \mathrm{va})_{\mathrm{t}}$ & $\begin{array}{c}59.9 \\
(1.69)\end{array}$ & & & $\begin{array}{c}49.4 \\
(1.34)\end{array}$ & $\begin{array}{c}45.2 \\
(1.23)\end{array}$ \\
\hline$(\dot{\mathrm{H}} / \mathrm{va})_{\mathrm{t}}$ & & $\begin{array}{l}-590.0 \\
(-0.98)\end{array}$ & & & $\begin{array}{l}-635.0 \\
(-1.07)\end{array}$ \\
\hline$(\mathrm{t} / \mathrm{va})_{\mathrm{t}}$ & & & $\begin{array}{l}-0.625 \\
(-1.41)\end{array}$ & $\begin{array}{l}0.917 \\
(1.01)\end{array}$ & $\begin{array}{l}0.605 \\
(0.64)\end{array}$ \\
\hline$S$ & 0.262 & 0.306 & 0.298 & 0.261 & 0.260 \\
\hline$\overline{\mathrm{R}^{2}}$ & $19.3 \%$ & $5.4 \%$ & $10.3 \%$ & $26.1 \%$ & $33.6 \%$ \\
\hline D.W. & 2.11 & 1.71 & 1.95 & 1.94 & 1.69 \\
\hline
\end{tabular}

(*) الم برشح البرنامج اية عو ائد اقتصادية معنوية احصائيا ، عند مستوى معنوية (F=4.00).

0

تشبر حصيلة الثقديرات اعلاه إلى ان راس المال البشري له اتار ايجابية

مقبولة (إحصائبا) على التقدم التكنولوجي في اتتنتين من المنظمــات الـــصناعية

التناث محل التجريب، وهما الكبرينية بالمقام الاول وبمعامل ثانير مرتقع نماما

حتى إذا قورن مع التقدير ات العالمية الواردة في المبحث السابق. وقد بلخغ هــــا

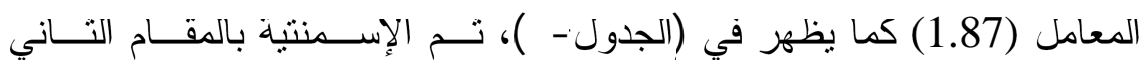

وبمعامل ناثير منو اضع قدره(0.23). اما في الغزل و النسيج فقد ظهـر تــاتيره

سلبيا على التقام التكنولوجي ولكن بمعامل منخفض و غير مقبول احصائبا.

وهذا يعني ان تتامي راس المال البشّري بقدر معين في صناعة الكبريت

يؤدي الى تز ايد معدلات الثقدم التكنولوجي بزهاء (1 AV\%)، وان هذا المتغيــر

لوحده يشرح نحو $25 \%$ (R² من النغيرات الحاصلة في تلك المعدلات (ف مي 
الانحدار البسيط).ومع إدخال النشاط الإبداعي (التطوير) المحلي و الاجنبي تصل هذه النسبة الى (39\%). وفي صناعة الاسمنت اشـارت التقدير ات الـــى ان تتــامي راس المـــال البشري بقدر معين يؤدي الى تز ايد معدلات التقدم التكنولوجي بنـسبة (سبr\%)

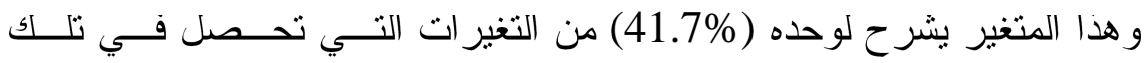
المعدلات (في الانحدار البسيط). اما المتغير ان الاخر ان وهما البحث و النطوير المحلي (الكلي) و الاجنبـي لإني

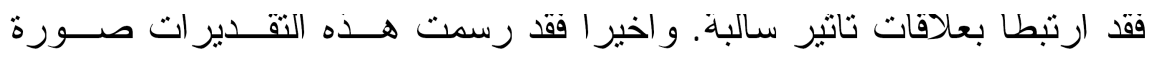

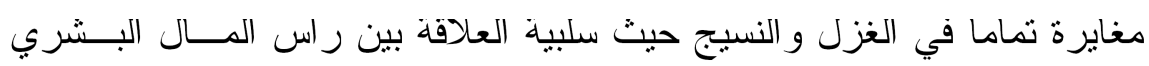
و التقدم التكنولوجي فيها، وان العامل الإبداعي الوحيد ايجابيا و المقبول إحصائيا

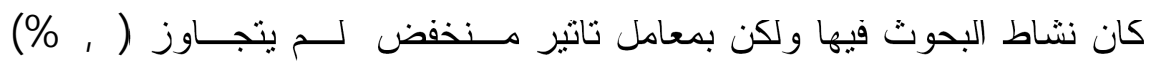
وبمقدرة توضيحية لم تصل (20\%) من النغير ات التكنولوجية الحاصلة فيها، لا

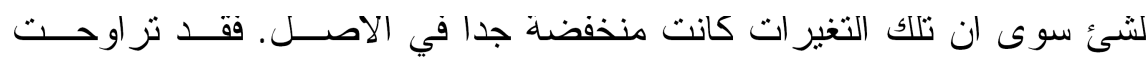

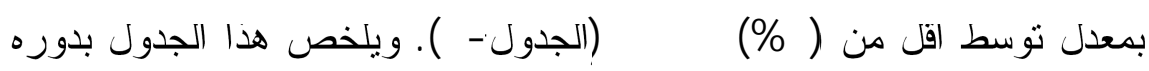
الصورة العامة للمؤشر ات الإبداعبة - التكنولوجية في الصناعات التلاث خــلال المدد الزمنية لكل منها.

و المحرك غير المحدد للنمو التكنولوجي هو تز اكم راس المال البـشري ونمو راسمال البحث و التطوير ـ و الاول يتاثر بالقر ارات و السياسات الاقتصادية

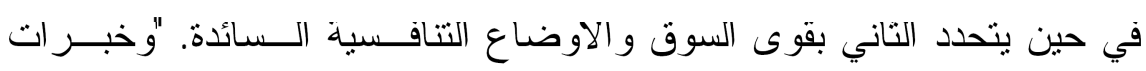
المنشاة المثر اكمة التي اكتسبتها بمرور الوقت نتيجة تجاربها و اســتفادتها مــن اخطائها تعد من الاصول المهمة التي يجب تتمينها عن طريق تطوير اســاليب 


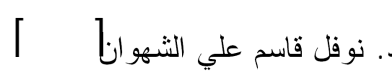
معلو مات الانتطة الإبداعية وتقدير .

العمل و استقطاب الكفاءات المتخصصة.. لكن معظم منشاتتا تغفل اهمبة الحفاظ على تلك المعرفة و إدارتها بشكل علمي"ر و إذا كان النمو الاقتصادي هو نتاج النمو في النشاط الاقتصادي الّاس فــان الاخير ما هو الا حصيلة تفاعل بين الموارد الاقتصادية المختلفـــة فــي بيئـــة

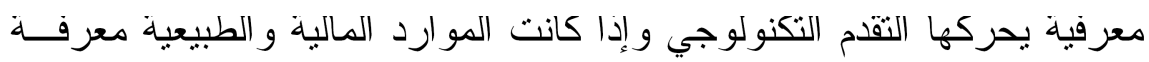

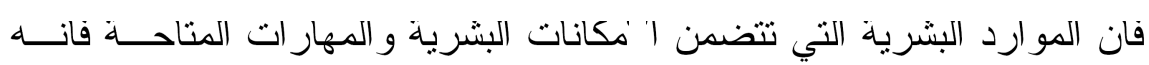
يتقدمها النز اكم في راس المال البشري.

الجدول-V: ملضص العلاهات المقدرة بين راس المال البشري، البحث والتطوير والتقدم التكنولوجي

\begin{tabular}{|c|c|c|c|}
\hline معادله التقدم & الاسمنت & الكبريت & الغزل و النسيج \\
\hline $\bar{\lambda}$ & $0.009(\quad)$ & $0.018(0.06)$ & $-0.02(-0.26)$ \\
\hline$\dot{H} / H$ & $0.23(1.88)$ & $1.87(2.26)$ & $-0.09(-0.15)$ \\
\hline Inn. & سلبي غيرمعنوي & $\begin{array}{c}\text { Kd: } 1.41 \\
(1.79)\end{array}$ & $\begin{array}{c}\text { Kr: } 0.09 \\
(1.84)\end{array}$ \\
\hline $\mathrm{t} / \mathrm{t}$ & سلبي غير معنوي & 0.05 (1.05) & $0.004(0.18)$ \\
\hline $\mathrm{R}^{2}$ & $41.7 \%$ & $39 \%$ & $19.8 \%$ \\
\hline
\end{tabular}

تبقى الإشكالية الجوهرية في كيفية الاستتمار فـي رصــيد راس المــال

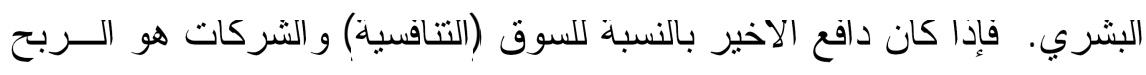

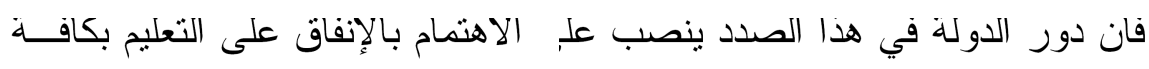
مر احله و الإنفاق على التنريب و النطويز و إعادة التاهيل وسن التشريعات التـي تكفل حق الملكية الفكرية. و العائد على الإبداعات وعلى راس المــال الفكـري كلها اشكال للمستثمار في الانشطة الإبداعبة تعكس: نو اضع نظــام المعلومــات

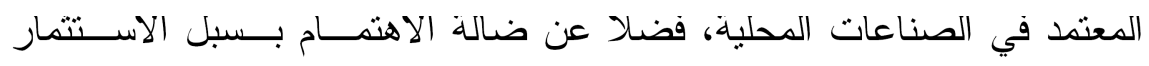


الافضل و المجدي في الإبداعات، و اخير ا بساطة الاهتمامات و القناعات باهمينها من اجل هدف اعلى منل النمو و التقدم. وحصبلة الاداء الكلي الايجابي نتركـز جوهريا على مستوى نظام معلومات الموارد البشرية و اهم جو انب هذا النظـــام

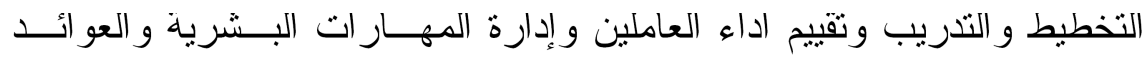

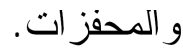

الجدول -1: الصورة العامه لمعلومات الاششطه الإبلاعيه مع التقدم التكنولوجي في المنظمات الصناعيه التلات

\begin{tabular}{|c|c|c|c|c|c|c|c|c|c|}
\hline \multicolumn{2}{|c|}{$\mathbf{R}^{2}$} & \multirow{2}{*}{ 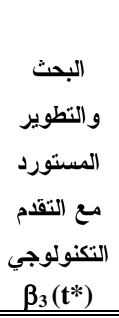 } & \multirow[b]{2}{*}{$\begin{array}{c}\text { التلافه مئ } \\
\text { التكنولوجي } \\
\beta_{2} \text { (t) }\end{array}$} & \multirow[b]{2}{*}{$\begin{array}{c}\text { الإبداعز } \\
\text { المؤثر } \\
\text { R\&DD }\end{array}$} & \multirow{2}{*}{ 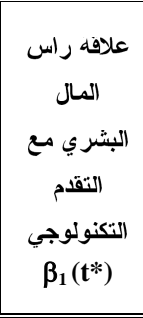 } & \multirow{2}{*}{$\begin{array}{l}\text { تر اكد } \\
\text { راس البشرل } \\
\text { H/C }\end{array}$} & \multirow{2}{*}{ 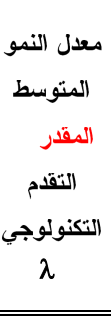 } & \multirow{2}{*}{ 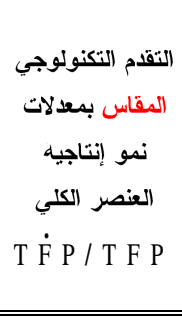 } & \multirow[b]{2}{*}{ الصناعه } \\
\hline المؤتر & $\mathrm{H} / \mathrm{C}$ & & & & & & & & \\
\hline $\mathrm{R}$ & $19.8 \%$ & معنوبية & (ايجابية & R البحث & $\begin{array}{c}-0.09 \\
(-0.15)^{*}\end{array}$ & $4.2 \%$ & -2 & $1.6 \%$ & والنسبيج \\
\hline .. & $25 \%$ & غعنير & (بجنوبية) & التطو ير D & $\begin{array}{c}2.18 \\
(2.70) * *\end{array}$ & $6.63 \%$ & 12.6 & $19.3 \%$ & الكبريت \\
\hline .. & $42 \%$ & معنية & (معنوية) & $R \& D$ & $\begin{array}{c}0.23 \\
(1.88) * *\end{array}$ & $10.3 \%$ & 10.0 & $19.4 \%$ & الاسمنت \\
\hline
\end{tabular}

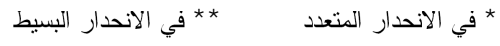

ومهما تتوسع الدراسات عن العلاقة بين الإبـــداع و النمــــ الاقتهـصادي

و انتشار المعرفة، فإنها تقى بحاجه الى فهم اعمق بالتعامل مع نمادج مبـسطة

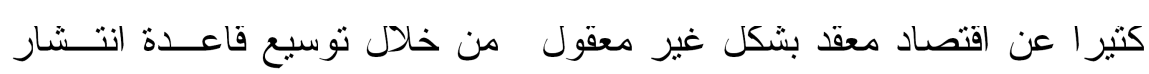

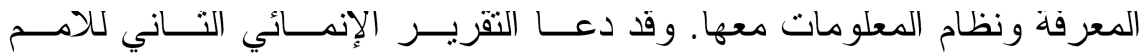




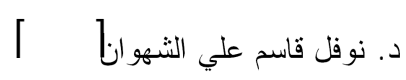
معلومات الانشطة الإبداعية و تقدير .r

المتحدة" لبناء مجتمع المعرفة في الدول النامية وخاصـــة العربيـــة وتــوطين

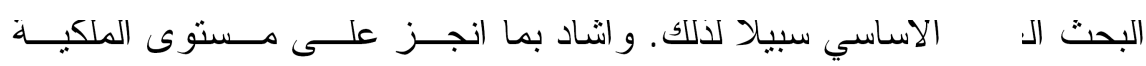
الفكرية و اكد و اقعيا على ان الملكية الفكرية تثكل احد القيود امام وصول الكتير

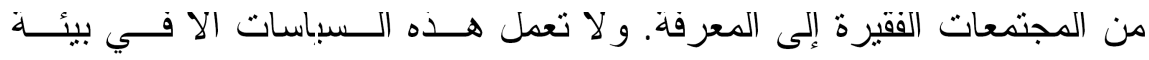

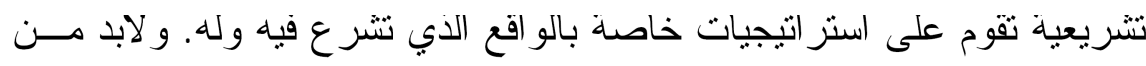

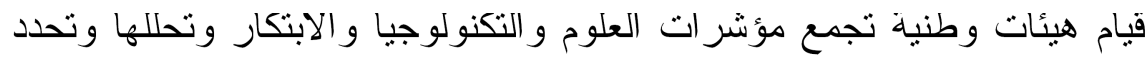

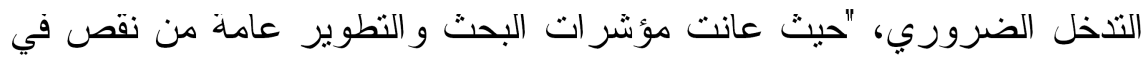

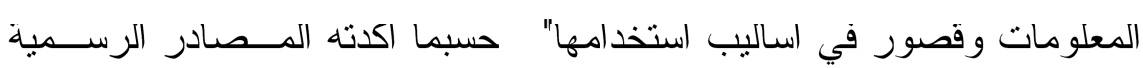
للامم المتحدة و اتبتته نتائج النقدير في هذه الدراسة.

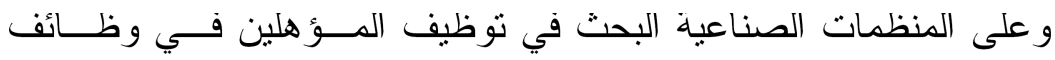

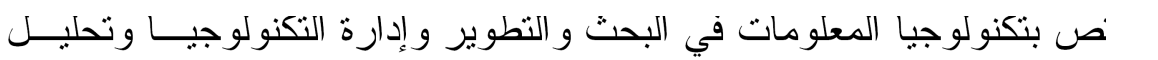

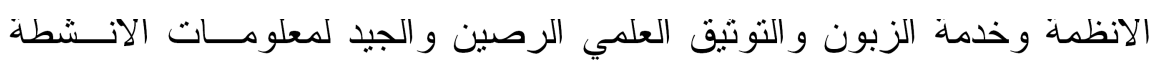

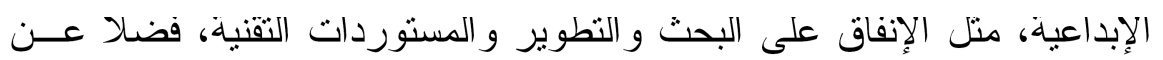

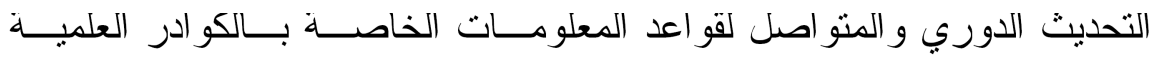
ونتاجاتها ومجالات تحفيز ها المطلوبة. و اخير ا مو اكبة النطور ات العالمية لـسبل

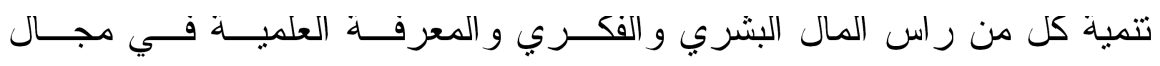
الاختصاص، و على المجتمع المنظمي الإسهام بمحاربة الفقر المعرفي بـ سلامة

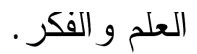

الملحق -1 : ملخص أسلوب قياس التقام التكنولوجي من دالة انتاج كوب -دوكلاس وتقاير معادلة التقام التكنولوجي لوني

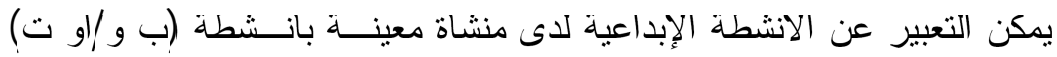

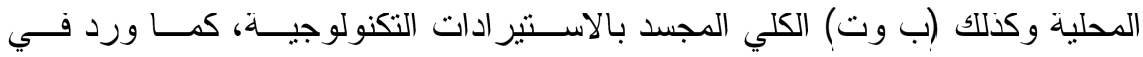


المبحث الثالث، وبصياغة بديلة تتضمن موارد بديلة متعددة تؤمن المنشاة من خلالهــــا

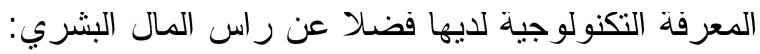

$Z_{i}=Z\left(H i, O_{T i}, P_{T i}\right)$

إذ ان : OTi : رصيد المنـشاة (i) مــن المعرفــة التقنيــة المحليــة او الخاصــة

،(Owned)

PTi

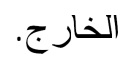

ورصيد المنشاة من المعرفة التكنولوجية الخاصة، يفترض بها دالة في جهود و انشطة

الإبداع الحالية و السابقة لها:

$$
H i=\sum \lambda_{i, j} H_{i, t-j}
$$

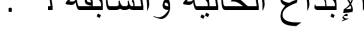

$$
\begin{aligned}
& \mathrm{O}_{\mathrm{Ti}}=\sum \mathrm{a}_{\mathrm{i}, \mathrm{j}} \mathrm{ORD}_{\mathrm{i}, \mathrm{t}-\mathrm{j}} \\
& \mathrm{P}_{\mathrm{Ti}}=\sum \mathrm{b}_{\mathrm{i}, \mathrm{j}} \mathrm{PRD}_{\mathrm{i}, \mathrm{t}-\mathrm{j}}
\end{aligned}
$$

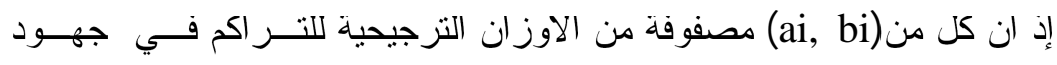
البحث و المعرفة و تقيس ناثير الفجوة الموزعة للفترة (j) وتعكس معدل اندثار وتقادم هذا الرصيد)(Obsolescence of R\&D) وقد استخدمت ترجمة مبسطة لهذه العلاقة:

$$
\mathrm{Q}=\mathrm{A}(\mathrm{t}) \mathrm{f}(\mathrm{K}, \mathrm{L}, \mathrm{H}, \mathrm{O}, \mathrm{P}, \mathrm{)}
$$

$$
\mathrm{Q}=\mathrm{Ae}^{\lambda t} \mathrm{~K}^{\alpha} \mathrm{L}^{1-\alpha} \mathrm{H}^{\varphi} \mathrm{O}^{\beta 1} \mathrm{P}^{\beta 2}
$$$$
\text { وباستخدام دالة إنتاج نوع (كوب--دوكلاس): (A) (A ) }
$$

$$
\text { H }
$$

A معلمة النمو غبر المجسد اللتكنولوجيا. A م: مرونات الإنتاج مع عو ائد حجم ثابتة للعمل ور اس المال.

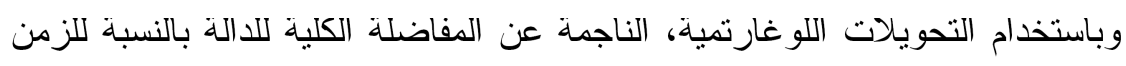

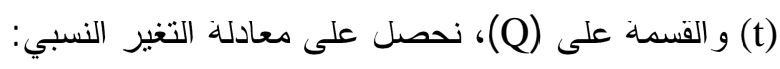


$\frac{\dot{Q}}{Q}=\frac{\dot{A}}{A}+A \frac{\partial f}{\partial K} \frac{\dot{K}}{Q}+A \frac{\partial f}{\partial L} \frac{\dot{L}}{Q}+A \frac{\partial f}{\partial O} \frac{\dot{H}}{Q}+A \frac{\partial f}{\partial P} \frac{\dot{P}}{Q}+A \frac{\partial f}{\partial P} \frac{\dot{O}}{Q}$

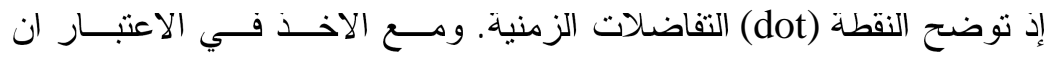

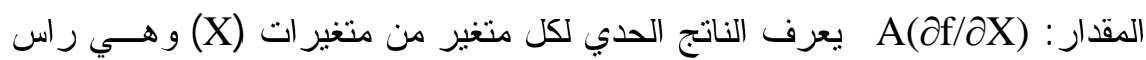

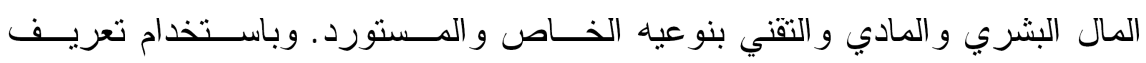
الإسهامات النسبية لكل من هذه المتغير ات تصبح المعادلة الاخبرة: $\dot{Q} / Q=\lambda+\alpha_{1}(\dot{K} / K)+\alpha_{2}(\dot{L} / L)+\phi(\dot{H} / H)+\beta_{1}(\dot{O} / O)+\beta_{2}(\dot{P} / P)$

ويعرف نمو الإنتاجية العنصر الكلي التكنولوجي المقاس بالمتبقي من معادلـــة التقــدم

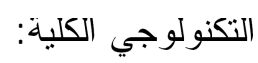
$\mathrm{TFPG}=\dot{\mathrm{Q}} / \mathrm{Q}-\alpha_{1}(\dot{\mathrm{K}} / \mathrm{K})-\alpha_{2}(\dot{\mathrm{L}} / \mathrm{L})=\lambda+\beta_{1}(\dot{\mathrm{O}} / \mathrm{O})+\beta_{2}(\dot{\mathrm{p}} / \mathrm{p})$

$$
\begin{aligned}
& \text { إذ ان معلمتي(ß) هما مرونتي الناتج لر اس المال التقني (المحلي و المستورد): } \\
& \beta_{1}=(\partial \mathrm{Q} / \partial \mathrm{O})(\mathrm{O} / \mathrm{Q}) \quad, \beta_{2}=(\partial \mathrm{Q} / \partial \mathrm{P})(\mathrm{P} / \mathrm{Q})
\end{aligned}
$$

وبتعويض قيمتي (A2،ر، (A2) في الطرف الايمن من معادلة التغير التقني:

$\mathrm{TFPG}=\theta+\rho_{1}(\dot{\mathrm{O}} / \mathrm{Q})+\rho_{2}(\dot{\mathrm{P}} / \mathrm{Q})$

و المعاملين (A10)

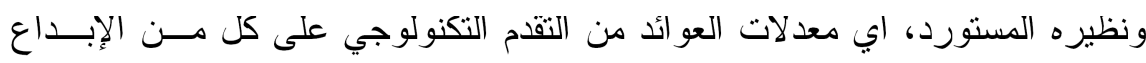
المحلي و المستورد على التزتيب. وان كل من (P,O) يمثل الوحدة القزارية (الحدية) لصاف الاستثمار (الخـاص) ف مي رصيد راس المال التقني.

الملحق -r: جذول الرموز و المختصر ات

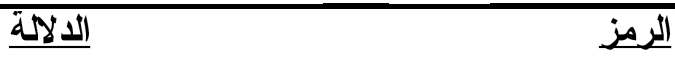

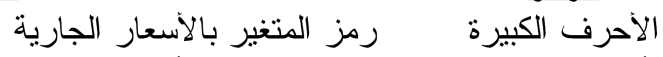

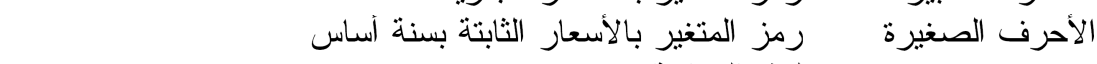
لهذه الدر اسة 
راس المال العامل في المنشأة ( j ) و المقاس في نهاية السنة I ) (فيها

مجموع عدد ساعات العمل الكلية السنوية فـي الــصناعة ( j ) مبهاعة خلال السنة مثلا عاعلات

( القيمة المضافة المحسوبة بتكلفة عناصر الإنتاج في الصناعة )

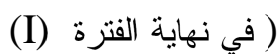

والإنفاق السنوي على الأبحاث التطبيقية والتجـــارب المختبريسـة و الميدانية و الموقعية الإنغية الإنفاق السنوي على النوفية التطوير الداخلي (إيــاعات ، تــدريب،

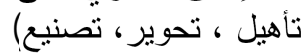

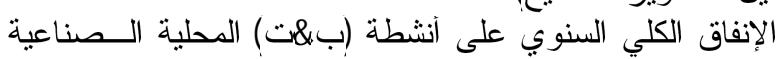

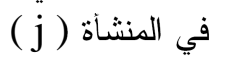

رأسمال المعرفة التي تمنلكها المنشأة ( j ) على الأبحاث النطبيقية

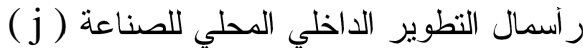

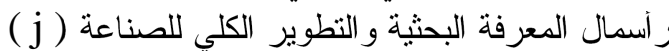
الإنفاق السنوي على (بكات) غير الَّباشر المجسد بمستوردات

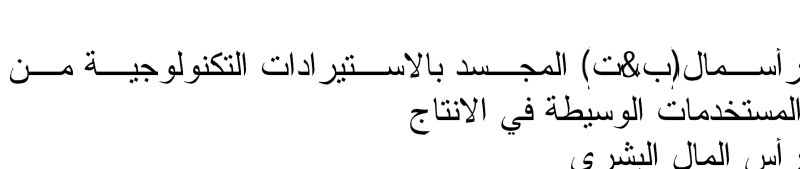
kH, kt, kr\&d, kr, Va, k, L تغير المتغير Z في الفترة

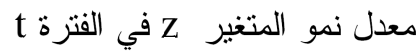
مرونات الناتج للعمل ور أس المال الطبيعي ولر أســمال (بكت) المحلي كثافة الإنفاق على النشاط الإبداعي X من القيمة المضافة t , r\&d, d, r

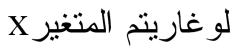
تغيرات إنتاجية العنصر الكلي (التكنولوجي) معدل نمو التغير التكنولوجي الخارجي غبر المجسد لفترة محددة

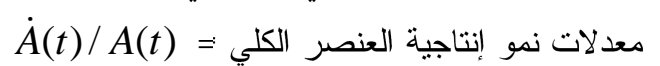

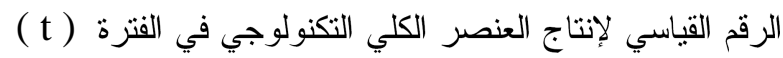

$\mathrm{k}$

$\mathrm{L}$

va

r

D

r\&d

$\mathrm{Kr}=\mathrm{R}$

$\mathrm{Kd}=\mathrm{D}$

$\mathrm{kr} \& \mathrm{~d}=\mathrm{R} \& \mathrm{D}$

$\mathrm{t}$

$\mathrm{Kt}=\mathrm{T}$

$\mathrm{Kh}=\mathrm{H}$

$\mathrm{z}$

$\Delta \mathrm{z}_{\mathrm{t}}=(\partial \mathrm{z} / \partial \mathrm{t})_{\mathrm{t}}$

$(\dot{z} / z)_{t}$

$\gamma, \beta, \alpha$

$\mathrm{x} / \mathrm{va}$

$\mathrm{x}$

$\log x$

TFP

$\lambda$

$T \dot{F P} / T F P$

$\mathrm{A}(\mathrm{t})$ 
Minitab Under Windows الملحق -r: البرمجية الأولى لخطوات ومر احل القياس تحت البرنآمج

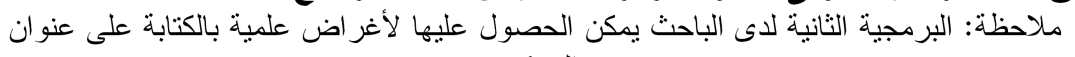

GMACRO

NNRR.MAC

name c1 'Output'

name c2 'Work'

name c3 'Capital'

name c4 ' $\mathrm{R}$ '

name $c 5$ 'D'

name c6 'R\&D'

name c7 'K.Res.'

name c8 'K.Dev.'

name c9 'K.R\&D

name c10 'Years'

name c11 'CPI'

name c12 'va'

pars $\mathrm{c} 4 \mathrm{c} 7$

pars c5 c8

pars c6 c9

let $\mathrm{c} 12=(\mathrm{c} 1 / \mathrm{c} 11) * 100$

name $\mathrm{c} 13$ ' $\mathrm{L}$ '

let $\mathrm{c} 13=\mathrm{c} 2 * 359 * 8$

name c14 'k'

let $\mathrm{c} 14=(\mathrm{c} 3 / \mathrm{c} 11)^{*} 100$

name $\mathrm{c} 15$ ' $\mathrm{Kr}$ '

let $\mathrm{c} 15=(\mathrm{c} 7 / \mathrm{c} 11) * 100$

name c16 'Kd'

let $\mathrm{c} 16=(\mathrm{c} 8 / \mathrm{c} 11) * 100$

name $\mathrm{c} 17$ 'Kr\&d'

let $\mathrm{c} 17=(\mathrm{c} 9 / \mathrm{c} 11) * 100$

name c18 'Logva'

$\log \mathrm{c} 12 \mathrm{c} 18$

name c19 ' $\log \mathrm{L}$ '

$\log \mathrm{c} 13 \mathrm{c} 19$

name c20 'Logk'

$\log \mathrm{c} 14 \mathrm{c} 20$

name c21 ' $\mathrm{LogKr}$

$\log \mathrm{c} 15 \mathrm{c} 21$

name c22 'LogKd'

Log c16 c22

name c23 'LogKr\&d'

$\log \mathrm{c} 17 \mathrm{c} 23$

read c196;

format (a17).

EQUATION NO. 1

end

print c196

name c24 = 'eq1'

\section{regr c18 2 c19 c20;}

constant;

coefficients 'eq1';

dw.

read c197;

format (a17)

EQUATION NO. 2

end

print c197

name c25 = 'eq2'

regr c18 3 c19 c20 c21;

constant;

coefficients 'eq2';

dw.

read c198;

format (a17)

EQUATION NO. 3

end

print c198

name c26 = 'eq3'

regr c18 3 c19 c20 c22;

constant;

coefficients 'eq3';

dw.

read c199;

format (a17).

EQUATION NO. 4

end

print c199

name c27 = 'eq4'

regr c18 3 c19 c20 c23;

constant;

coefficients 'eq4';

dw.

read c200;

format (A60).

Choice The More Significant

Equation From Eq2,Eq3,Eq4

(i.e. The Highest T-Value of

$\mathrm{Kr}, \mathrm{Kd}$ or $\mathrm{Kr} \& \mathrm{~d}$ ) Run

One of The Following Files To

Execute Your Choice \{ 1-

EFF1.MTB , 2- EFF2.MTB , 3-

EFF3.MTB \}

end

print c200 
در اسات إقليمية 7 (10)

[ [ [ [ مركز الدراسات الإقليمية

This document was created using $>$ S 


\title{
Innovational Activities Information And The Estimation Of Technological Promotion Sources
}

\author{
Nawfal Kasim Ali Al-Shahwan \\ Head, Economic Studies Department, \\ Regional Studies Center, The University Of \\ Mosul
}

\begin{abstract}
This study aims at analyzing the reality of the Information Systems for the industrial innovation activities and testing the range of its setting the key gates of the technological promotion, throughout estimating the imparts of Human Capital H/C and research and development $R \& D$ on technological progress at the level of many industrial organizations in Iraq.

The access to those two aims approved the guess and the hypothesis of the study, that's the existence of the local basement for setting the process of scientific and technologic catching-up. This is done by getting significant and positive effects of $\mathrm{H} / \mathrm{C}$ accumulation and $\mathrm{R} \& \mathrm{D}$ growth on the technological change accounted within the industries of Cement, Sulphur, and Weavings.

The study reached many conclusive results prevailed the vital importance for those factors of the innovational activities (i.e. R\&D and $\mathrm{H} / \mathrm{C}$ ) in technological progress, but no returns from the last one on those factors. The study also found some negative relations due to; either the serious uninteresting of the sources of technological promotion; or to the poor information system. These results in turn suggest the necessity of adopting the relevant policies and generating it to the all scientific and industrial fields.
\end{abstract}


${ }^{1}$ Smith, Adam, An Inquiry to the Nature and Causes of The Wealth of Nations, $6^{\text {th }}$. ed, New York, 1950, P. 264.

${ }^{2}$ Schumpeter J.A., The History of Economic Analysis, McGraw-Hill, New York, 1900.

${ }^{3}$ Schumpeter J.A., The Theory of Economic Development, Harvard University Press, Cambridge of Mass., 1934.

${ }^{4}$ Solow, R. M., “ Technical Change and Aggregate Production Function", Review of Economics and Statistics, 1957, 28, 117-124

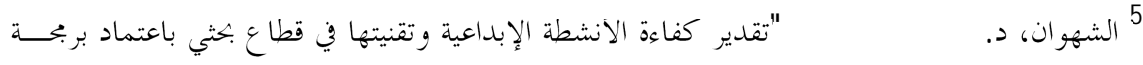

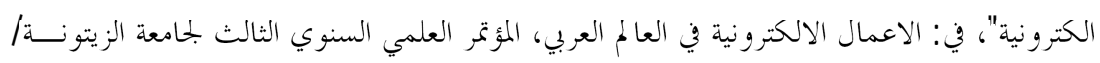

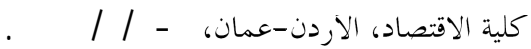

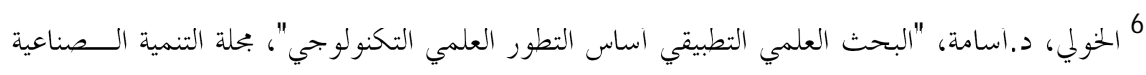

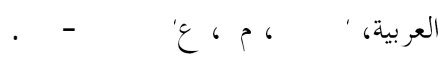

7 Carnoy, M. "Education and Economic Development, The First Generation", Economic Development and Cultural Change, 1977, 25.

${ }^{8}$ Nelson, Richard R. and Edmund S. Phelps, "Investment in Humans, Technological Diffusion, and Economic Growth", The American Economic Review, 1966, 2, 69-75.

${ }^{9}$ Terleckyj, Nester E.(ed.), The State of Science and Research: Some New Evidence, National Planning Association, Washing D.C., Colorado, 1977.

${ }^{10}$ Nelson, Richard R., "Less Developed Countries, Technology Transfer and Adaptation : The Role of Indigenous Science Community", Economic Development and Cultural Change, 1974, 23, 61-78.

${ }^{11}$ Kinndleberger, Charles P. and Bruce Herrick , Economic Development, $3^{\text {rd }}$ ed. McGraw-Hill, Tokyo, 1977.

${ }^{12}$ Garcia-Blanch, Francisco, "An Empirical Inquiry into the Nature of South Korean Economic Growth," ID Warking Paper No. 74, Center for International Development, Harvard Univ., 2002.

${ }^{13}$ Mayer, David and Andrew Foster, Scale, Technological Change: Manufacturing and Development in Mexico, A Part of the W.B. Project:

"Knowledge in Latin America and Caribean", New York, 2002. 
${ }^{14}$ Ribeiro, Maria-Joao, "A Non scale Growth Model With R\&D and Human Capital Accumulation," No 574 Warwick Univ. Economic Research Paper, Department of Economics,2002, on:

http://www2.warwick.ac.uk/fac/soc/economics/research/papers/twerp574. pdf

${ }^{15}$ Kuwahara, Shiro, "Endogenous Growth with R\&D, Human

Capital Accumulation and Population Growth," on:

http://www.miejigakuin.ac.ip/ jea/612a/kuwahara.pdf, 2004.

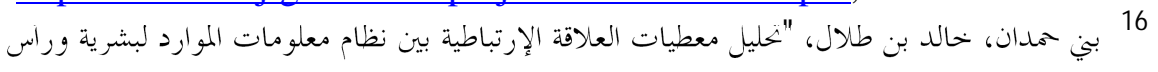

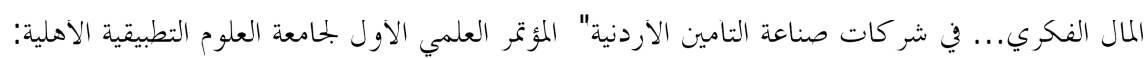

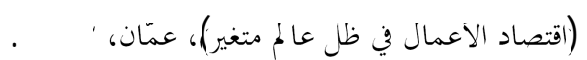

${ }^{17}$ Griliches, Zvi and Dale W. Jorgenson, Sources of Measured Productivity Change: Capital Input", The American Economic Review, 1966, 2, 50-61.

18 Terleckyj, Nester E., "Direct and Indirect Effects of Industrial Research and Development on Productivity Growth", in : New Developments in Productivity measurement and Analysis, by: J.W. Kendrick and B.N. Vaccara (ed.), University of Chicago Press, Chicago, 1980, 359-377.

${ }^{19}$ Lichtenberg, Frank R., "R\&D Investment and International Productivity Differences", NBER, Working Paper No. 4161,Cambridge, 1992.

${ }^{20}$ Zeng, Jinli, Essays on R\&D and Economic Growth: Research and Development, Human Capital, Ph.D. Dissertation, McMaster University (Canada), 1995.

21 Toya, Hedeki, Mark Shedmore and Remond Robertson, "Why Are Estimates of Human Capital's Contributes to Growth So Small?", www.macalester.edu/ Robertson/TSR1.pdf, 2004.

222

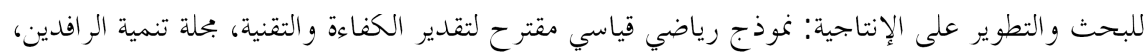

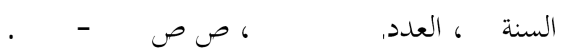

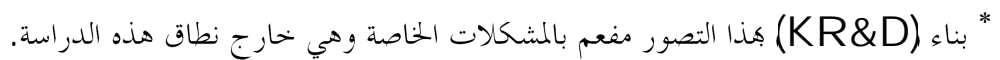

${ }^{23}$ Terleckyj, Nester E., (1980), Op. Cit. 
24 إن بناء سلاسل راس المال البشري او الابداعي عملية محفوفة بالكثير من الصعوبات وهي خارج نطاق

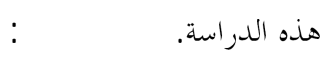

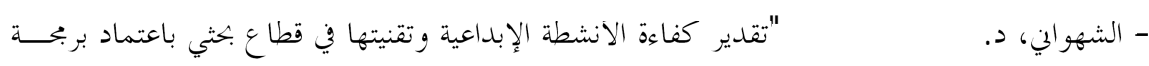

$$
\text { الكترونية"، مصدر سابق. }
$$

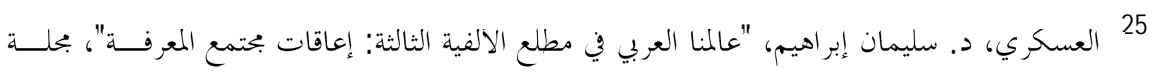

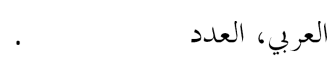

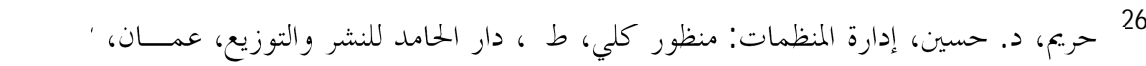

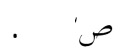

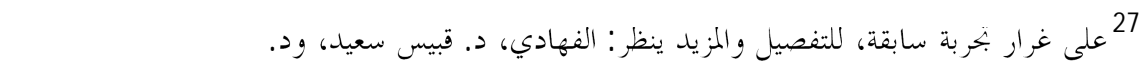

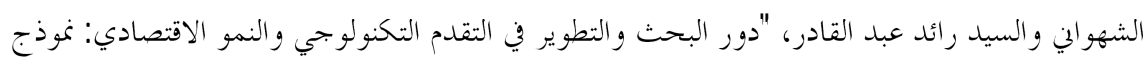

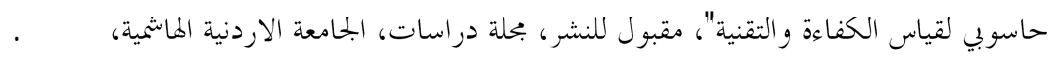

${ }^{28}$ Terleckyj, Nester E., ., (1980), Ibid.

${ }^{29}$ Nelson, Richard R., "Institutions Supporting Technical Advance in Industry", The American Economic Review, 1986 ,2, 186-189.

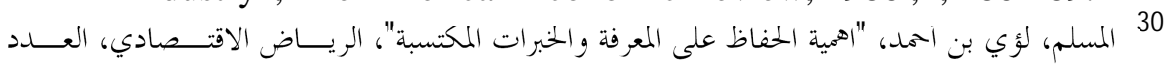

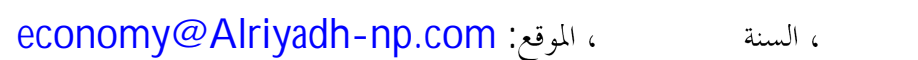

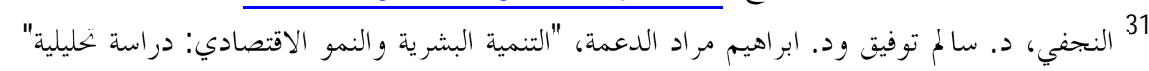

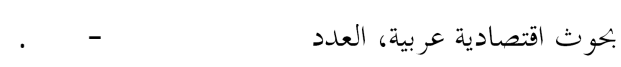

${ }^{32}$ Agawal, Ajay, Innovation, Growth Theory, and the Role of Knowledge Spillovers, Innovation Analysis Bulletin, vol.4, no. 3, Nov. 2002.

33 خلف، د. ريما، (مقابلة السيد ياسر ابو هلالة مع مدير المكتب العربي لبرنامج الامم المتحدة الإنــائي)

www .All azeera. net/mritens/streams/audio/2003/11/4/1184170113. asf.

للتفصيل: ينظر التقرير الإنمائي الثاني للامم المتحدة، و الاسكوا: استعراض الإنتاجيسـة وانــشطة التنميسـة

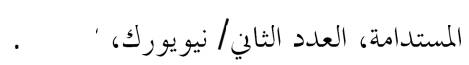

( 34 